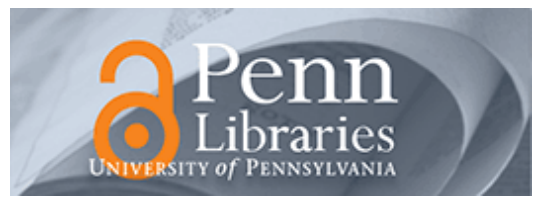

University of Pennsylvania

ScholarlyCommons

Finance Papers

Wharton Faculty Research

$5-2004$

\title{
Local Revenue Hills: Evidence from Four U.S. Cities
}

Andrew F. Haughwout

Robert P. Inman

University of Pennsylvania

Steven Craig

Thomas Luce

Follow this and additional works at: https://repository.upenn.edu/fnce_papers

Part of the Finance and Financial Management Commons, Income Distribution Commons, and the Taxation Commons

\section{Recommended Citation}

Haughwout, A. F., Inman, R. P., Craig, S., \& Luce, T. (2004). Local Revenue Hills: Evidence from Four U.S. Cities. The Review of Economics and Statistics, 86 (2), 570-585. http://dx.doi.org/10.1162/ 003465304323031120

This paper is posted at ScholarlyCommons. https://repository.upenn.edu/fnce_papers/219

For more information, please contact repository@pobox.upenn.edu. 


\title{
Local Revenue Hills: Evidence from Four U.S. Cities
}

\begin{abstract}
We provide estimates of the effects and long-run elasticities of the tax base with respect to tax rates for four large U.S. cities: Houston (property taxation), Minneapolis (property taxation), New York City (property, general sales, and income taxation), and Philadelphia (property, gross receipts, and wage taxation). Results suggest that three of our cities are near the peaks of their revenue hills; Minneapolis is the exception. A significant negative effect of a balanced-budget increase in city property tax rates on the city property base is interpreted as a capitalization effect and suggests that marginal increases in city spending do not provide positive net benefits to property owners. Estimates of the effects of taxes on city employment levels for New York City and Philadelphia'the two cities for which employment series are available-show the local income and wage tax rates have significant negative effects on city employment levels. Cuts in these tax rates are likely to be an economically cost-effective way to increase city jobs. High taxes, sometimes by diminishing consumption of the taxed commodities, and sometimes by encouraging smuggling, frequently afford a smaller revenue to government than what might be drawn from more moderate taxes. (Adam Smith, The Wealth of Nations, book V, chapter II.) It is a signal advantage of taxes on articles of consumption that they contain in their own nature a security against excess. If duties are too high, they lessen the consumption; the collection is eluded; and the product to the treasury is not so great as when they are confined within proper and moderate bounds. (Alexander Hamilton, "Further Defects of the Present Constitution," Federalist Papers, No. 21.) If a tax is gradually increased from zero up to the point where it becomes prohibitive, its yield is at first nil, then increase by small stages until it reaches a maximum, after which it gradually declines until it becomes zero again. [Jules Dupuit, "On the Measurement of Utility from Public Works," reprinted in K. Arrow and Tibor Scitovsky, Readings in Welfare Economics (Homewood, IL: Richard D.Irwin, 1969).] Nor should the bbargument seem strange that taxation may be so high as to defeat its object, and that, given sufficient time to gather the fruits, a reduction bbbbbof taxation will run a better chance than increase of balancing the budget. (John Maynard Keynes, Collected Works of John Maynard Keynes, St. Martin's Press, p. 338.)

Disciplines

Finance and Financial Management | Income Distribution | Taxation
\end{abstract}




\title{
LOCAL REVENUE HILLS: EVIDENCE FROM FOUR U.S. CITIES
}

\author{
Andrew Haughwout, Robert Inman, Steven Craig, and Thomas Luce*
}

\begin{abstract}
We provide estimates of the effects and long-run elasticities of the tax base with respect to tax rates for four large U.S. cities: Houston (property taxation), Minneapolis (property taxation), New York City (property, general sales, and income taxation), and Philadelphia (property, gross receipts, and wage taxation). Results suggest that three of our cities are near the peaks of their revenue hills; Minneapolis is the exception. A significant negative effect of a balanced-budget increase in city property tax rates on the city property base is interpreted as a capitalization effect and suggests that marginal increases in city spending do not provide positive net benefits to property owners. Estimates of the effects of taxes on city employment levels for New York City and Philadelphia- the two cities for which employment series are available-show the local income and wage tax rates have significant negative effects on city employment levels. Cuts in these tax rates are likely to be an economically costeffective way to increase city jobs.
\end{abstract}

High taxes, sometimes by diminishing consumption of the taxed commodities, and sometimes by encouraging smuggling, frequently afford a smaller revenue to government than what might be drawn from more moderate taxes. (Adam Smith, The Wealth of Nations, book V, chapter II.)

It is a signal advantage of taxes on articles of consumption that they contain in their own nature a security against excess ... If duties are too high, they lessen the consumption; the collection is eluded; and the product to the treasury is not so great as when they are confined within proper and moderate bounds. (Alexander Hamilton, "Further Defects of the Present Constitution," Federalist Papers, No. 21.)

If a tax is gradually increased from zero up to the point where it becomes prohibitive, its yield is at first nil, then increase by small stages until it reaches a maximum, after which it gradually declines until it becomes zero again. [Jules Dupuit, "On the Measurement of Utility from Public Works," reprinted in K. Arrow and Tibor Scitovsky, Readings in Welfare Economics (Homewood, IL: Richard D. Irwin, 1969).]

Nor should the argument seem strange that taxation may be so high as to defeat its object, and that, given sufficient time to gather the fruits, a reduction of taxation will run a better chance than increase of balancing the budget. (John Maynard Keynes, Collected Works of John Maynard Keynes, St. Martin's Press, p. 338.)

\section{Introduction}

$\mathrm{F}$ ROM Smith to Dupuit to Keynes, understanding the equilibrium effects of taxation on the level and location of economic activities has long been of scholarly interest to public finance economists. From our first Secretary of the Treasury Alexander Hamilton to today's mayors, governors, and presidents, the issue has been of no less importance to

Received for publication April 24, 2000. Revision accepted for publication June 20, 2003.

* Federal Reserve Bank of New York; University of Pennsylvania and NBER; University of Houston; and Ameregis, Inc., respectively.

The authors would like to thank the Zell-Lurie Center for Real Estate Research (Wharton School) and the National Science Foundation for financial support. We received valuable comments and advice from our referee, from Howard Chernick, Joe Gyourko, Todd Sinai, Robert Rich, Nick Souleles, John Quigley, and Jake Vigdor, and from seminar participants at Princeton University, the Universities of Delaware, Maryland, and Pennsylvania, the ZEW Federalism Conference (University of Mannheim), the 2000 Norwegian Tax Forum, the 2000 NBER Summer Institute, the 2000 APPAM meetings, and the 2000 Southern Economic Association meetings. The research and views presented here are those of the authors alone and do not reflect the official position of the Federal Reserve Bank of New York or the NBER. elected officials. Today, almost no city, state, or national budget fails to mention the wisdom of controlling taxes to enhance economic development and job growth. During periods of fiscal crises, as in FY 2003, predicting the effects of a local tax increases on equilibrium revenues becomes essential if mayors or governors are to design credible strategies for balancing city and state budgets, both for today and for the longer run. While there is general agreement that local taxes matter, we are still far from a consensus as to how much. ${ }^{1}$

This paper provides econometric estimates of the effects of local taxation on local economic activities in four large U.S. cities: Houston, Minneapolis, New York City, and Philadelphia. Given those estimates, we then compute each city's revenue hill, known perhaps more familiarly as the city's "Laffer curve." Our evidence places Houston, New York City, and Philadelphia near the peaks of their respective revenue hills, whereas Minneapolis remains comfortably down its revenue hill with significant additional taxing capacity. In all four of our sample cities, however, we find the marginal tax dollar fails to deliver a full dollar of capitalized public service benefits, suggesting that distributive local politics may be setting our cities' budgets, at least on the margin. For our two cities for which we have annual employment data, New York and Philadelphia, we find that tax increases reduce city jobs and that lowering city taxes is likely to be a cost-effective way to increase city employment.

\section{The Effects of Taxation in an Open City Economy}

Large cities offer only one of many competitive locations for residents and firms. Capital, labor, and households are mobile, both across locations in a given economic region and between regions. Capital located in a city must earn the competitive rate of return, goods produced within the city must sell at competitive prices, commuting labor working in the city must earn a competitive wage, and residents living and working within the city must receive an overall level of utility comparable to that available outside the city.

Haughwout and Inman $(2001,2002)$ have presented a general equilibrium model of city fiscal competition with just these features. Their analysis is an extension of the

\footnotetext{
${ }^{1}$ Bartik (1991) still provides the best overall summary of what we know about the effects of local taxation on local economic activity generally. Additional studies since Bartik's survey confirm his conclusion that taxes have significant negative effects on the location of economic activity in open economies. On the effects of city taxation on city economic activity, see Inman (1995) for Philadelphia and Mark, McGuire, and Papke (2000) for Washington, DC. On the adverse economic effects of state taxation, see Hines (1996) and Goolsbee and Maydew (2000) for U.S. states, and Feld and Kirchgassner (2003) for Swiss cantons. And finally, at the country level, see Desai, Foley, and Hines (2002) for strong evidence that taxation influences the level of foreign direct investment across economic regions.
} 
pioneering model of Rosen (1979) and Roback (1982) of firm and labor locations in a spatial economy. The HaughwoutInman model defines an equilibrium wage and an equilibrium land value for the city as well as equilibrium quantities of city residential housing and consumption, firm use of capital, land, and labor, and finally, total city output. Each endogenous city price and quantity is a function of a vector of all city tax rates $(\boldsymbol{\tau})$ and the level of city services $(G)$, the market interest rate $(r)$, alternative wages $(q)$ for workers who commute, the world price for city exports $(\equiv 1)$, the level of profit available to firms in their next best alternative $\left(\Pi_{0} \equiv 0\right)$, and the level of utility available to city residents in their next best location $\left(V_{0}\right)$. The vector of city tax rates $(\tau)$ includes a tax on residential and commercial property $\left(\tau_{p}\right)$, a tax on resident consumption $\left(\tau_{s}\right)$, taxes on resident $\left(\tau_{w}\right)$ and commuter $\left(\tau_{m}\right)$ labor incomes, and a tax on gross receipts from city production $\left(\tau_{x}\right)^{2}$

The Haughwout-Inman model differs from the more familiar Tiebout-Oates capitalization specification (dating from 1969) of local public economies by explicitly including firms as well as households as market participants setting equilibrium prices and quantities. Endogenous city prices and quantities define in turn city tax bases per resident. The city's property tax base $\left(B_{p}\right)$ is defined as the sum of the endogenous market value of residential housing and residential land plus endogenous firm capital and commercial land divided by endogenous city population. The city sales tax base $\left(B_{s}\right)$ equals endogenous consumption per resident within the city. The city's resident earned income tax base $\left(B_{w}\right)$ equals the endogenous resident wage. The city's nonresident earned income tax base $\left(B_{m}\right)$ equals the exogenous commuter wage times the endogenous number of city commuterworkers divided by the endogenous city population. Finally, the city's gross receipts tax base $\left(B_{x}\right)$ equals the endogenous city output per resident. Each tax base depends on all city tax rates $\left[\tau=\left(\tau_{p}, \tau_{s}, \tau_{w}, \tau_{m}, \tau_{x}\right)\right]$ and city public services $(G)$, exogenous market prices $(q, 1$, $r$ ), and the attractiveness of alternative locations available to city firms $\left(\Pi_{0} \equiv 0\right)$ and households $\left(V_{0}\right)$. Generally,

$$
B_{t}=B_{t}\left(\tau, G ; q, 1, r, V_{0}\right)
$$

where $t=p, s, w, m$, or $x$ for each of the five possible city tax bases.

A correct specification of a city's revenue hill first relates city tax rates to city tax bases and then to city revenues, but only after removing the effect of tax rates on the ability of

\footnotetext{
2 The model and our empirical analysis do not include a tax on firm excess profits. Since capital is freely mobile across cities, capital must earn the competitive rate of return. There are, therefore, no excess profits to be taxed. The analysis does allow the city to differentially tax capital in place, however. This can be accomplished by differentially taxing land and capital through the city's property tax; see Haughwout and Inman (2002).
}

the city to provide public services. Revenue hills are an equilibrium representation and allow for the balancedbudget effect of rates on base; see Inman (1989). Changes in city tax rates change the level of public goods provided within the city through the city's budget constraint, specified as

$$
G \equiv \frac{\sum_{t} \tau_{t} B_{t}(\tau, G ; \cdot)+Z}{c},
$$

where $\sum_{t} \tau_{t} B_{t}(\tau, G ; \cdot)$ is city total tax revenues, $\boldsymbol{\tau}$ is the vector of all city tax rates, $Z$ is nontax city revenues (exogenous fees and grants), and $c$ is an exogenous price index for local public service. Solving the budget identity for $G$ and substituting into equation (1) provides the general equilibrium, balanced-budget relationship between city tax rates and a city tax base: ${ }^{3}$

$$
B_{t}=b_{t}\left(\tau ; Z, c, r, q, 1, V_{0}\right) .
$$

Tax revenues raised from any city tax rate will therefore equal

$$
T_{t}=\tau_{t} \cdot b_{t}\left(\tau ; Z, c, r, q, 1, V_{0}\right)
$$

for each local tax $(t=p, s, w, m, x)$. The city's equilibrium revenue hill is now defined as the aggregate of all city revenues for each combination of city tax rates, specified as

$$
R E V=\sum_{t} \tau_{t} \cdot b_{t}\left(\boldsymbol{\tau} ; Z, c ; r, q, 1, V_{0}\right)+Z
$$

A small increase $\left(\Delta \tau_{j}\right)$ in any individual tax rate results in an equilibrium balanced-budget change in total city revenues of

$$
\Delta R E V=\Delta \tau_{j} \cdot B_{j}+\sum_{t} \tau_{t} \cdot\left[\frac{B_{t} \varepsilon_{t j} \Delta \tau_{j}}{\tau_{j}}\right] .
$$

The first term of equation (5) measures the direct revenue effect of a small change in one of the city's tax rates $\left(\tau_{j}\right)$, holding fixed that tax's own tax base. The second term measures the indirect equilibrium revenue effects of the rate change after all local tax bases, including the tax's own base, have fully responded to the change in the local rate and to the balanced-budget adjustments in $G$. The expression within brackets measures the change in each tax base because of the small change in $\tau_{j}$, where $\varepsilon_{t j}$ is the equilibrium elasticity of the base $B_{t}$ with respect to changes in rate

\footnotetext{
${ }^{3}$ To ensure an equilibrium level of tax base and therefore tax revenues, we must assume the conditions for the implicit function theorem hold for the system of tax base equations plus the budget identity. Sufficient for a stable equilibrium is that $c>\sum_{t} \tau_{t} \partial B_{t} / \partial G$, or in words, increasing the public good $G$ by one unit does not bring in more in tax revenues $\left(\Sigma_{t} \tau_{t}\right.$ $\left.\partial B_{t} / \partial G\right)$ than it costs to produce the good $(c)$; see Haughwout and Inman (2001).
} 
$\tau_{j}$. In the special case where all cross-base effects of a change in $\tau_{j}$ are zero $\left(\varepsilon_{t j}=0, j \neq t\right)$, we obtain the familiar specification that

$$
\Delta R E V=\Delta \tau_{j} \cdot B_{j}+\tau_{j} \cdot\left[\frac{B_{j} \varepsilon_{j j} \Delta \tau_{j}}{\tau_{j}}\right]=B_{j}\left(1+\varepsilon_{j j}\right) \Delta \tau_{j} .
$$

In this case, when a tax base's own rate-to-base elasticity is $\varepsilon_{j j}>-1$ (for example, -0.5 ), then tax revenues increase with small increases in a tax's own tax rate and the city will be on a rising portion of its revenue hill $\left(\Delta R / \Delta \tau_{j}>0\right)$. When $\varepsilon_{j j}=-1$, the city is at the top of its revenue hill $\left(\Delta R / \Delta \tau_{j}=0\right)$, and when $-1>\varepsilon_{j j}$ (for example, -1.5$)$, the city is on the falling side of the revenue hill $\left(\Delta R / \Delta \tau_{j}<\right.$ $0)$. Since tax revenues are allocated to the purchase of public goods when specifying the tax base and revenue hill equations, it is possible for a city's $\varepsilon_{t j}$ 's to be positive-for example, when land taxes are used to finance valued public goods as in Brueckner (1982). The actual values of a city's $\varepsilon_{t j}$ 's is an empirical issue. Section III provides estimates of equation (2) for each of our four sample cities for each city tax base for which sufficient data are available.

\section{Data and Estimation}

\section{A. Data}

Houston, Minneapolis, New York City, and Philadelphia each use the local property tax. The property tax base per resident $\left(B_{p}\right)$ is the aggregate market value per resident of all taxable property within the city as estimated from each city's tax roles using arm's-length sales of city properties. Minneapolis uses only a property tax. Houston also uses a general sales tax, but there is insufficient variation in the sales tax rate to estimate a sales tax base equation.

In addition to the property tax, New York also uses a general sales tax and a local income tax. New York City's sales tax base per resident $\left(B_{s}\right)$ is the city's reported aggregate retail sales from establishment tax returns for the given fiscal year. The city's income tax base per resident $\left(B_{w}\right)$ uses the federal income tax definition of taxable income and equals the fiscal year's aggregate taxable earned (wage) and unearned (investment) income as reported by city residents. ${ }^{4}$

In addition to the property tax, Philadelphia also levies a resident and a nonresident (commuter) wage tax, a gross receipts tax on all business sales within the city, and a $1 \%$ additional rate to the $6 \%$ statewide sales tax.

\footnotetext{
${ }^{4}$ The income tax base for New York City is largely (75\%) a wage tax base; see Tax Revenue Forecasting Documentation: Financial Plan, FY 1994-98, City of New York, Office of Management and Budget, 1994. Prior to 2000, New York City also imposed a nonresident income tax, but its rates and revenues are low and its rate variation is insufficient for empirical analysis.
}

Philadelphia does not separately report resident and nonresident wage tax bases on an annual basis; we therefore use the aggregate resident plus nonresident wage tax base denominated as base per resident (and denoted as $B_{w+m}$ ). The Philadelphia gross receipts tax base per resident $\left(B_{x}\right)$ is the city's reported taxable receipts from business sales within Philadelphia. There is insufficient variation over time in the Philadelphia sales tax surcharge and the state sales tax rate; thus, we could not estimate a sales tax base equation for Philadelphia.

In all our cities, the city property tax rate $\left(\tau_{p}\right)$ is the effective average tax rate defined as the city's proportional mill rate times the market-value-weighted average rate of property assessment within the city. ${ }^{5}$. Statutory tax rates are used for the resident income and sales taxes in New York City and for the wage and gross receipt taxes in Philadelphia. New York City's income tax is a progressive tax; we define $\tau_{w}$ for purposes of our analysis as the city's top marginal income tax rate. Using the top statutory rate as our measure of $\tau_{w}$ avoids a direct source of simultaneity in our estimated base equations. Since our measure of Philadelphia's wage tax base is the sum of resident and commuter taxable wages, we use a weighted average of the two rates (denoted as $\tau_{w+m}$ ) as the city's wage tax rate. ${ }^{6}$ Importantly, there is significant variation, both up and down, in each of our city's local tax rates over our sample years; see appendix A.

An important issue for the estimation of the causal effects of tax rates on city tax base will be the exogeneity of changes in the city's tax rates. We want to rule out the possibility that any observed correlation between rates and base is due to reverse causation, that is, where strong local economies permit rate reductions and weak economies require rate increases. Our analysis uses three alternative identification strategies. First, for all taxes, there is a 10- to 12-month lag between the announcement of changes in city tax rates and our measured realizations of changes in city tax bases. Rate decisions for each fiscal year are made in the spring prior to the July 1 start of that new fiscal year. Our measures of city base, however, are from data reported at the end of each fiscal year after all tax bases and revenues have been officially recorded. Therefore, within our data is a "natural" 1-year lag between the announcement of a fiscal year's tax rate and the realization of that fiscal year's tax base. If local

\footnotetext{
${ }^{5}$ Houston, Minneapolis, and New York City have different classes of property with different effective tax rates for each class. For these cities we create a single tax-based weighted average of the separate property tax rates as our measure of $\tau_{p}$. The ratios of assessment to market value are based upon market value as estimated from an annual sample of arm'slength sales of market properties.

${ }^{6}$ The Philadelphia wage tax rate used to explain the aggregate resident plus nonresident wage tax base is a weighted average of the resident $\left(\tau_{w}\right)$ and nonresident $\left(\tau_{m}\right)$ wage tax rates, specified as $\tau_{w+m}=0.7 \tau_{w}+0.3 \tau_{m}$, where the weights were provided by the Philadelphia Department of Revenue, based on periodic surveys. We thank Mr. Michael Isard for these data.
} 
economic actors react to rather than anticipate local rate changes, then ordinary least squares (OLS) estimates using our 1-year lagged rates will identify the causal effect of rates on base. Second, for New York City and Philadelphia, sales and income tax rates are set not by city politicians but by state legislators and state politics. The well-publicized but largely unsuccessful efforts by Mayor Bloomberg in the winter of 2003 to persuade the New York State legislature to increase city income tax rates illustrate the importance of state politics to changes in city rates. If state decisions on local tax rates are determined by statewide political events uncorrelated with the year-to-year variation in the New York City and Philadelphia local economies, then even if local actors anticipate these rate changes, the OLS estimates will still identify the causal effect of rates on base. Finally, we use an instrumental variable (IV) methodology to identify the plausibly exogenous determinants of changes in local rates, where the instruments are exogenous national or state-level fiscal events likely to influence changes in local tax rates but thought to be uncorrelated with contemporaneous changes in the city's local economy.

In addition to local tax rates, other independent variables in each tax base equation include: exogenous nonmatching federal and state grants-in-aid to the city (including school aid) minus net spending by the city on welfare services $(Z) ;{ }^{7}$ exogenous determinants of the cost of local public goods $(c)$ measured by changes in the national industrial producer price index $(1994=\$ 1.00)$; interest rates $(r)$ measured by the AAA corporate borrowing rate; nonresident wages $(q)$ measured by national (not an endogenous local) average hourly earnings in nonagricultural industries; and the national (not the endogenous local) rate of unemployment $(U E)$ and the national (not the endogenous local) rate of violent crime (CRIME) as measures of the relative attractiveness to city residents of moving to other locations $\left(V_{0}\right){ }^{8}$

Exogenous economic or policy events should also be included in our analysis to control for possible omitted variable bias. National economic events thought to impact the local economy include the annual change in real oil prices $[\triangle O I L P$, from Rich and Raymond (1997)] for Houston, in real national farm income $(\triangle F A R M Y)$ for Minneapolis, in the deflated Dow-Jones Industrial Average $(\triangle D O W)$ for New York City, and in real national

\footnotetext{
${ }^{7}$ Since the mobile middle class and firms determine land values and wages within the city, we use only exogenous aid which can be allocated to middle class and/or business services. Thus city welfare spending is subtracted from total exogenous grants-in-aid.

${ }^{8}$ City-specific annual crime rates for our sample cities and their surrounding suburbs are not available on a consistent basis over our sample years. Cullen and Levitt (1999) have examined the effects of crime on city economies using decade-to-decade changes in city-specific crime rates to explain decade-to-decade changes in city population, and they find significant negative effects, particularly for upper-income and educated households, of city crime on city population in their sample of 127 large U.S. cities.
}

health care spending $(\triangle H E X P)$ for Philadelphia. Policy events thought to impact our cities include a large infusion of state economic development construction by Minnesota (STADIUM, for Minneapolis) and the adoption of new state income taxes by New Jersey (NJITX, for both New York City and Philadelphia) and by Connecticut (CTITX, for New York City). We will also test for any additional influence of national mayoral reputation on city tax base (Giuliani in New York City and Rendell in Philadelphia). Appendix A summarizes all data for our four cities.

Augmented Dickey-Fuller tests (available upon request) reveal each of our national and city time series is a firstorder integrated $[\mathrm{I}(1)]$ process. Given these results, all equations are estimated in first differences. We also tested for the possibility of pooling our four sample cities to obtain more precise estimates of the effects of tax rates on base, at least for property taxation, which all four cities use. We reject pooling as a preferred estimation strategy for our four cities. ${ }^{9}$ Therefore, all base equations are estimated separately for each city.

\section{B. Estimation: Core OLS Results}

Tables 1-3 present our core estimates of the effects of changes in city tax rates on changes in city tax base. Table 1 specifies changes in the property tax base per resident $\left(\Delta B_{p}\right)$ as a function of a constant term, balanced-budget changes in current and lagged city effective property tax rates $\left(\Delta \tau_{p}\right)$, the national rate of unemployment $(\Delta U E)$, federal and state aid (including school aid) to the city net of welfare spending $(\Delta Z)$, and the national rate of violent crime $(\triangle C R I M E)$. In this first-difference specification, the constant term measures the average annual rate of growth in each city tax base.

In all four cities, $\Delta \tau_{p}$ has a statistically significant and quantitatively important negative effect on the rate of change of the city's property tax base, and the effect is felt within the fiscal year of the rate change. An $F$-test for the statistical significance of lagged rate changes shows lagged changes to be statistically insignificant for Houston and New York and only marginally significant in Minneapolis and Philadelphia; see table 1. The insignificance of lags longer than one fiscal year suggests that the primary effect of changes in city property tax rates is an impact capitalization effect on the value of existing housing and business structures, rather than a longer-run investment effect.

Table 1 also reports the effects of broader national trends on property values in the cities. Cyclical swings in

\footnotetext{
${ }^{9}$ A pooled regression regressing $\Delta B_{p}$ on a constant term, $\Delta \tau_{p}, \Delta U E$, $\Delta Z$, and $\triangle C R I M E$ has an unadjusted $R^{2}=0.28$. The pooled regression of $\Delta B_{p}$ on city-specific constants and each variable interacted with a city-specific indicator has an unadjusted $R^{2}=0.53$. An $F$-test for the significance of all interaction terms as a test of validity of pooling rejects the null hypothesis of pooling at the 0.02 level of significance: $F_{15,74}=$ 2.507. Significant interactions were observed for all tax rates.
} 
TABLE 1.-PROPERTY TAXATION ${ }^{\mathrm{a}}$

\begin{tabular}{|c|c|c|c|c|c|c|c|c|c|c|c|c|}
\hline & \multicolumn{3}{|c|}{ Houston } & \multicolumn{3}{|c|}{ Minneapolis } & \multicolumn{3}{|c|}{ New York } & \multicolumn{3}{|c|}{ Philadelphia } \\
\hline & $\Delta B_{p}$ & $\Delta B_{p}$ & $\Delta B_{p}$ & $\Delta B_{p}$ & $\Delta B_{p}$ & $\Delta B_{p}$ & $\Delta B_{p}$ & $\Delta B_{p}$ & $\Delta B_{p}$ & $\Delta B_{p}$ & $\Delta B_{p}$ & $\Delta B_{p}$ \\
\hline Constant & $\begin{array}{c}793.2 \\
(635.7)\end{array}$ & $\begin{array}{c}845.1 \\
(618.3)\end{array}$ & $\begin{array}{l}1006.3 \\
(868.2)\end{array}$ & $\begin{array}{c}914.8^{*} \\
(237.1)\end{array}$ & $\begin{array}{c}951.9^{*} \\
(218.1)\end{array}$ & $\begin{array}{c}919.0^{*} \\
(243.1)\end{array}$ & $\begin{array}{c}102.7 \\
(289.1)\end{array}$ & $\begin{array}{l}-13.6 \\
(303.8)\end{array}$ & $\begin{array}{c}14.7 \\
(301.7)\end{array}$ & $\begin{array}{c}72.5 \\
(127.3)\end{array}$ & $\begin{array}{c}47.5 \\
(144.0)\end{array}$ & $\begin{array}{c}47.5 \\
(144.0)\end{array}$ \\
\hline$\Delta \tau_{p}$ & $\begin{array}{r}-14,116.2 * \\
(5,565.0)\end{array}$ & $\begin{array}{r}-11,995.5^{*} \\
(5,488.2)\end{array}$ & $\begin{array}{r}-15,657.5^{*} \\
(7,085.1)\end{array}$ & $\begin{array}{r}-2,402.0^{*} \\
(920.1)\end{array}$ & $\begin{array}{r}-2,484.6^{*} \\
(865.0)\end{array}$ & $\begin{array}{c}-1,609.2 \\
(1,256.2)\end{array}$ & $\begin{array}{r}-10,660.9^{*} \\
(1,420.5)\end{array}$ & $\begin{array}{r}-10,532.4 * \\
(1,487.3)\end{array}$ & $\begin{array}{r}-9,785.7^{*} \\
(1,694.8)\end{array}$ & $\begin{array}{r}-3,129.1^{*} \\
(599.4)\end{array}$ & $\begin{array}{r}-3,079.9^{*} \\
(615.0)\end{array}$ & $\begin{array}{r}-2,965.7^{*} \\
(688.4)\end{array}$ \\
\hline$\Delta \tau_{p}(-1)$ & - & - & $\begin{array}{r}-1,771.3 \\
(6,464.7)\end{array}$ & - & - & $\begin{array}{c}-2,100.1 \\
(1,241.4)\end{array}$ & - & - & $\begin{array}{c}-756.5 \\
(1,828.8)\end{array}$ & - & - & $\begin{array}{l}-35.3 \\
(757.1)\end{array}$ \\
\hline$\Delta \tau_{p}(-2)$ & - & - & $\begin{array}{c}5,348.3 \\
(5,833.9)\end{array}$ & - & - & $\begin{array}{c}-963.8 \\
(1,096.3)\end{array}$ & - & - & $\begin{array}{c}1,224.7 \\
(1,963.4)\end{array}$ & - & - & $\begin{array}{r}-1,538.4^{*} \\
(723.5)\end{array}$ \\
\hline$\Delta \tau_{p}(-3)$ & - & - & $\begin{array}{r}-5,785.4 \\
(5,911.5)\end{array}$ & - & - & $\begin{array}{r}-560.0 \\
(967.0)\end{array}$ & - & - & $\begin{array}{r}-3,188.5 \\
(1,778.0)\end{array}$ & - & - & $\begin{array}{r}-1,470.2 \\
(674.3)\end{array}$ \\
\hline$\Delta U E$ & - & $\begin{array}{c}493.8 \\
(567.0)\end{array}$ & $\begin{array}{c}703.7 \\
(654.9)\end{array}$ & - & $\begin{array}{c}166.0 \\
(238.0)\end{array}$ & $\begin{array}{c}-187.3 \\
(354.4)\end{array}$ & - & $\begin{array}{c}212.2 \\
(329.9)\end{array}$ & $\begin{array}{c}185.8 \\
(334.7)\end{array}$ & - & $\begin{array}{c}-179.9 \\
(136.0)\end{array}$ & $\begin{array}{c}-202.0 \\
(137.5)\end{array}$ \\
\hline$\Delta Z$ & - & $\begin{array}{l}24.0 \\
(22.2)\end{array}$ & $\begin{array}{c}16.3 \\
(25.6)\end{array}$ & - & $\begin{array}{c}2.6 \\
(1.9)\end{array}$ & $\begin{array}{c}1.0 \\
(2.1)\end{array}$ & - & $\begin{array}{c}1.4 \\
(1.4)\end{array}$ & $\begin{array}{c}0.4 \\
(1.6)\end{array}$ & - & $\begin{array}{c}0.1 \\
(1.9)\end{array}$ & $\begin{array}{c}-0.2 \\
(2.4)\end{array}$ \\
\hline$\triangle C R I M E$ & - & $\begin{array}{c}-39.5^{*} \\
(17.5)\end{array}$ & $\begin{array}{r}-47.8^{*} \\
(22.1)\end{array}$ & - & $\begin{array}{r}-14.9^{*} \\
(6.6)\end{array}$ & $\begin{array}{r}-14.3 \\
(7.3)\end{array}$ & - & $\begin{array}{c}7.7 \\
(9.9)\end{array}$ & $\begin{array}{c}10.3 \\
(10.1)\end{array}$ & - & $\begin{array}{c}5.3 \\
(4.3)\end{array}$ & $\begin{array}{c}6.9 \\
(4.6)\end{array}$ \\
\hline D.W. & 1.32 & 1.25 & 1.18 & 1.24 & 1.50 & 2.03 & 1.11 & 1.42 & 1.31 & 1.49 & 1.77 & 2.02 \\
\hline $\bar{R}^{2}$ & 0.16 & 0.31 & 0.27 & 0.18 & 0.32 & 0.33 & 0.61 & 0.61 & 0.61 & 0.47 & 0.47 & 0.53 \\
\hline$\varepsilon_{B, \tau}$ & $\begin{array}{r}-0.89^{*} \\
(0.35)\end{array}$ & $\begin{array}{r}-0.76^{*} \\
(0.35)\end{array}$ & $\begin{array}{c}-1.13 \\
(0.82)\end{array}$ & $\begin{array}{r}-0.16^{*} \\
(0.06)\end{array}$ & $\begin{array}{r}-0.17^{*} \\
(0.06)\end{array}$ & $\begin{array}{r}-0.36^{*} \\
(0.11)\end{array}$ & $\begin{array}{r}-0.77^{*} \\
(0.10)\end{array}$ & $\begin{array}{r}-0.76^{*} \\
(0.11)\end{array}$ & $\begin{array}{r}-0.90^{*} \\
(0.15)\end{array}$ & $\begin{array}{r}-0.41 * \\
(0.08)\end{array}$ & $\begin{array}{r}-0.41^{*} \\
(0.08)\end{array}$ & $\begin{array}{r}-0.80 * \\
(0.23)\end{array}$ \\
\hline $\begin{array}{l}F(\Delta \tau(-3)) \\
(p \text {-value })\end{array}$ & - & - & $\begin{array}{c}1.05 \\
(0.39)\end{array}$ & - & - & $\begin{array}{c}2.06 \\
(0.14)\end{array}$ & - & - & $\begin{array}{l}1.18 \\
(0.33)\end{array}$ & - & - & $\begin{array}{c}2.44 \\
(0.09)\end{array}$ \\
\hline
\end{tabular}

a Standard errors for each estimated coefficient are reported within parentheses. D.W. is the Durbin-Watson test statistic for serial correlation. $\bar{R}^{2}$ is the coefficient of determination corrected for degrees of freedom. The elasticity of tax base with respect to tax rate $\left(\varepsilon_{B, \tau}\right)$ is based on the marginal effect of rates on the tax base, calculated for the most recent fiscal year's tax base and tax rate for each city. Elasticities reported in columns with lagged rate changes are for the longer run. $F(\Delta \tau(-3))$ is the $F$-statistic for the null hypothesis that three lagged changes in rates jointly have no influence on change in tax base.

* Coefficient's $t$-statistic $\geq 2.00$

the national economy as measured by $\Delta U E$ have no important effects on property values, though, as we will see in table $2, \Delta U E$ does affect jobs and sales by businesses in the cities. Holding property tax rates fixed, an increase in federal or state transfers to the city $(\Delta Z)$ means additional public spending. If this additional spending is permanent and benefits property owners, then
$\Delta Z$ should be capitalized into higher values. We find no evidence of favorable capitalization.

Changes in the national rate of violent crimes ( $\triangle C R I M E)$, which varied significantly over our sample period and is highly correlated with urban crime rates, should also be capitalized into local property values. This is the case for Houston and Minneapolis, where the estimated elasticity of property values

Table 2.-SAles, Gross Receipts, and Income TaXation ${ }^{\mathrm{a}}$

\begin{tabular}{|c|c|c|c|c|c|c|c|c|c|c|c|c|}
\hline & \multicolumn{3}{|c|}{ Sales: New York } & \multicolumn{3}{|c|}{ Gross Receipts: Philadelphia } & \multicolumn{3}{|c|}{ Income: New York } & \multicolumn{3}{|c|}{ Wage: Philadelphia } \\
\hline & $\Delta B_{s}$ & $\Delta B_{s}$ & $\Delta B_{s}$ & $\Delta B_{x}$ & $\Delta B_{x}$ & $\Delta B_{x}$ & $\Delta B_{w}$ & $\Delta B_{w}$ & $\Delta B_{w}$ & $\Delta B_{w+m}$ & $\Delta B_{w+m}$ & $\Delta B_{w+m}$ \\
\hline Constant & $\begin{array}{c}52.9 \\
(75.4)\end{array}$ & $\begin{array}{c}24.3 \\
(79.1)\end{array}$ & $\begin{array}{c}27.0 \\
(84.0)\end{array}$ & $\begin{array}{c}349.5^{*} \\
(166.5)\end{array}$ & $\begin{array}{l}471.0^{*} \\
(184.9)\end{array}$ & $\begin{array}{c}512.5^{*} \\
(190.7)\end{array}$ & $\begin{array}{c}380.7 \\
(207.0)\end{array}$ & $\begin{array}{c}384.6 \\
(209.3)\end{array}$ & $\begin{array}{c}397.7 \\
(200.4)\end{array}$ & $\begin{array}{l}114.9 \\
(67.2)\end{array}$ & $\begin{array}{l}103.4 \\
(70.6)\end{array}$ & $\begin{array}{c}96.3 \\
(74.6)\end{array}$ \\
\hline$\Delta \tau_{s} ; \Delta \tau_{x}$ & $\begin{array}{r}-1,262.0^{*} \\
(241.3)\end{array}$ & $\begin{array}{r}-1,144.1^{*} \\
(259.5)\end{array}$ & $\begin{array}{r}-1,226.6^{*} \\
(275.3)\end{array}$ & $\begin{array}{r}-18,701.3^{*} \\
(3,672.4)\end{array}$ & $\begin{array}{r}-16,937.3^{*} \\
(3,627.5)\end{array}$ & $\begin{array}{r}-16,734.9^{*} \\
(4,228.2)\end{array}$ & - & - & - & - & - & - \\
\hline$\Delta \tau_{s}(-1) ; \Delta \tau_{x}(-1)$ & - & - & $\begin{array}{c}165.3 \\
(262.1)\end{array}$ & - & - & $\begin{array}{r}-1,506.9 \\
(4,837.0)\end{array}$ & - & - & - & - & - & - \\
\hline$\Delta \tau_{s}(-2) ; \Delta \tau_{x}(-2)$ & - & - & $\begin{array}{l}-213.6 \\
(253.5)\end{array}$ & - & - & $\begin{array}{r}-5,857.7 \\
(4,487.1)\end{array}$ & - & - & - & - & - & - \\
\hline$\Delta \tau_{w} ; \Delta \tau_{w+m}$ & - & - & - & - & - & - & $\begin{array}{r}-2,480.2^{*} \\
(543.4)\end{array}$ & $\begin{array}{r}-2,172.6^{*} \\
(569.7)\end{array}$ & $\begin{array}{r}-2,297.3^{*} \\
(531.6)\end{array}$ & $\begin{array}{c}-225.7 \\
(252.9)\end{array}$ & $\begin{array}{r}-210.3 \\
(235.9)\end{array}$ & $\begin{array}{r}-182.9 \\
(242.5)\end{array}$ \\
\hline $\begin{array}{l}\Delta \tau_{w}(-1) \\
\quad \Delta \tau_{w+m}(-1)\end{array}$ & - & - & - & - & - & - & - & - & $\begin{array}{c}1,014.5 \\
(511.1)\end{array}$ & - & - & $\begin{array}{c}232.8 \\
(258.8)\end{array}$ \\
\hline $\begin{array}{l}\Delta \tau_{w}(-2) \\
\quad \Delta \tau_{w+m}(-2)\end{array}$ & - & - & - & - & - & - & - & - & $\begin{array}{r}-837.4 \\
(563.0)\end{array}$ & - & - & $\begin{array}{l}-35.4 \\
(267.0)\end{array}$ \\
\hline$\Delta U E$ & - & $\begin{array}{r}-158.1 \\
\quad(88.7)\end{array}$ & $\begin{array}{r}-146.0 \\
(91.0)\end{array}$ & - & $\begin{array}{c}-312.3 \\
(177.6)\end{array}$ & $\begin{array}{c}-347.2 \\
(183.9)\end{array}$ & - & $\begin{array}{c}-286.1 \\
(236.6)\end{array}$ & $\begin{array}{c}-347.8 \\
(226.5)\end{array}$ & - & $\begin{array}{r}-147.0^{*} \\
(63.6)\end{array}$ & $\begin{array}{r}-142.5^{*} \\
(66.6)\end{array}$ \\
\hline$\Delta Z$ & - & $\begin{array}{c}0.4 \\
(0.4)\end{array}$ & $\begin{array}{c}0.5 \\
(0.4)\end{array}$ & - & $\begin{array}{r}-1.8 \\
(2.2)\end{array}$ & $\begin{array}{c}-2.7 \\
(2.4)\end{array}$ & - & $\begin{array}{r}0.15 \\
(1.0)\end{array}$ & $\begin{array}{c}0.2 \\
(1.0)\end{array}$ & & $\begin{array}{c}0.7 \\
(0.9)\end{array}$ & $\begin{array}{c}0.5 \\
(0.9)\end{array}$ \\
\hline$\triangle C R I M E$ & - & $\begin{array}{c}0.3 \\
(2.5)\end{array}$ & $\begin{array}{c}0.22 \\
(2.6)\end{array}$ & - & $\begin{array}{c}-7.3 \\
(5.2)\end{array}$ & $\begin{array}{c}-8.5 \\
(5.6)\end{array}$ & - & $\begin{array}{c}-7.0 \\
(6.5)\end{array}$ & $\begin{array}{c}-7.3 \\
(6.0)\end{array}$ & - & $\begin{array}{c}-1.3 \\
(2.0)\end{array}$ & $\begin{array}{c}-1.8 \\
(2.4)\end{array}$ \\
\hline D.W. & 1.35 & 1.11 & 1.03 & 1.94 & 2.28 & 2.28 & 2.51 & 2.49 & 2.48 & 1.37 & 1.53 & 1.47 \\
\hline $\bar{R}^{2}$ & 0.40 & 0.41 & 0.40 & 0.44 & 0.49 & 0.49 & 0.41 & 0.41 & 0.49 & -0.01 & 0.15 & 0.12 \\
\hline$\varepsilon_{B, \tau}$ & $\begin{array}{r}-0.52 * \\
(0.10)\end{array}$ & $\begin{array}{c}-0.47^{*} \\
(0.11)\end{array}$ & $\begin{array}{c}-0.50^{*} \\
(0.20)\end{array}$ & $\begin{array}{r}-0.21^{*} \\
(0.04)\end{array}$ & $\begin{array}{r}-0.19^{*} \\
(0.04)\end{array}$ & $\begin{array}{r}-0.27^{*} \\
(0.12)\end{array}$ & $\begin{array}{r}-0.53 * \\
(0.11)\end{array}$ & $\begin{array}{r}-0.47^{*} \\
(0.12)\end{array}$ & $\begin{array}{r}-0.46^{*} \\
(0.20)\end{array}$ & $\begin{array}{r}-0.06 \\
(0.07)\end{array}$ & $\begin{array}{r}-0.06 \\
(0.07)\end{array}$ & $\begin{array}{r}-0.004 \\
(0.14)\end{array}$ \\
\hline $\begin{array}{l}F(\Delta \tau(-2)) \\
(p \text {-value })\end{array}$ & - & - & $\begin{array}{c}0.58 \\
(0.56)\end{array}$ & - & - & $\begin{array}{c}0.96 \\
(0.39)\end{array}$ & - & - & $\begin{array}{c}2.89 \\
(0.07)\end{array}$ & - & - & $\begin{array}{c}0.46 \\
(0.64)\end{array}$ \\
\hline
\end{tabular}

${ }^{a}$ Standard errors for each estimated coefficient are reported within parentheses. D.W. is the Durbin-Watson test statistic for serial correlation. $\bar{R}^{2}$ is the coefficient of determination corrected for degrees of freedom. The elasticity of tax base with respect to tax rate $\left(\varepsilon_{B, \tau}\right)$ is based on the marginal effect of rates on the tax base, calculated for the most recent fiscal year's tax base and tax rate for each city. Elasticities reported in columns with lagged rate changes are for the longer run. $F(\Delta \tau(-2))$ is the $F$-statistic for the null hypothesis that two lagged changes in rates jointly have no influence on change in tax base.

$*$ Coefficient's $t$-statistic $\geq 2.00$ 
Table 3.-Estimated Own and Cross Tax Rate Elasticities ${ }^{\mathrm{a}}$

\begin{tabular}{|c|c|c|c|c|c|c|}
\hline & \multicolumn{3}{|c|}{ New York } & \multicolumn{3}{|c|}{ Philadelphia } \\
\hline & $\Delta B_{p}$ & $\Delta B_{s}$ & $\Delta B_{w}$ & $\Delta B_{p}$ & $\Delta B_{x}$ & $\overline{\Delta B_{w+m}}$ \\
\hline$\Delta \tau_{p}$ & $\begin{array}{r}-.81^{*} \\
(.11)\end{array}$ & $\begin{array}{c}.05 \\
(.09)\end{array}$ & $\begin{array}{c}-.18 \\
(.24)\end{array}$ & & & \\
\hline$\Delta \tau_{s}$ & $\begin{array}{c}.04 \\
(.09)\end{array}$ & $\begin{array}{r}-.22 * \\
(.08)\end{array}$ & $\begin{array}{c}-.13 \\
(.35)\end{array}$ & & & \\
\hline$\Delta \tau_{w}$ & $\begin{array}{c}.09 \\
(.05)\end{array}$ & $\begin{array}{c}-.04 \\
(.04)\end{array}$ & $\begin{array}{r}-.45^{*} \\
(.13)\end{array}$ & & & \\
\hline
\end{tabular}

${ }^{a}$ Estimated elasticities of each tax base to a corresponding rate change (standard errors in parentheses). Each $\Delta B$ equation includes the changes in all three tax rates as well as $\Delta U E, \Delta Z$ and $\triangle C R I M E$ as independent variables. Elasticities are calculated for the most recent fiscal year's tax base and tax rate for each city.

* Estimated elasticity's $t$-statistic $\geq 2.00$.

with respect to the national crime rate is -0.50 (s.e. $=0.22$ ) for Houston, and -0.27 (s.e. $=0.12$ ) for Minneapolis. We find no effect of changes in national crime rates on New York City and Philadelphia property values. ${ }^{10}$

Table 1 also reports the estimated elasticity of cities' property tax bases with respect to changes in their property tax rates. All reported elasticities are computed for the most recent year in each city sample. When lagged rates are included, the reported elasticity is the implied longer-run elasticity. Houston and New York, and Philadelphia after three years, show base elasticities which are statistically indistinguishable from -1 . Barring significant cross-base effects (see table 3 ), these three cities are very close to the top of their respective revenue hills, at least along the path marked "Property Taxation." Minneapolis is safely below the peak of its revenue hill. See figure 1 below.

The estimates in table 1 allow us to infer the efficiency of a marginal dollar of city property taxation, at least from the perspective of city property owners. As specified by equation (2) above and as estimated in table 1, the effect of rate changes on property values provides an estimate of the joint effect on city property values of changes in city tax rates and associated spending. The impact (first-year) effect of the tax and spending increase provides an estimate of the capitalized net benefits of taxation for city residents and firms. ${ }^{11}$

The market value $(M V)$ of city property is defined as the discounted stream of market rents $(R): M V=R / r$. Rents equal the rents paid for the "private" attributes of the property $\left(R_{\mathrm{pr}}\right)$ plus the annual benefits of the public services provided at the location less the property taxes

\footnotetext{
${ }^{10}$ We also tested for the effects of changes in local public good costs $(\Delta c)$, national interest rates $(\Delta r)$, and-for Philadelphia-nonresident wages $(\Delta q)$ on changes in local property values; individually or as a group, these variables were generally statistically insignificant, and their inclusion left the estimated effect of tax rates on tax base unaffected.

${ }^{11}$ There is the question of whether households and firms interpret our observed tax rate changes as temporary or permanent. If temporary, we should expect the estimated coefficients in the tax base equations to be approximately 0 . The fact that we find significant coefficients suggest taxpayers view these as permanent changes affecting future economic rents.
}

paid on the property $\left(T_{p}\right): R \simeq R_{\mathrm{pr}}+v G-T_{p}$, where $v$ is a dollar measure of a property owner's benefit from local services $(G)$. Assuming a (locally) linear technology relating services received to taxes paid, $G=\Phi T_{p}$, then $R \simeq R_{\mathrm{pr}}+(v \Phi-1) T_{p}$, where $v \Phi-1$ represents the net benefit of an additional dollar of local taxation. Further, $T_{p}=\tau_{p} \cdot M V$. A small increase $\Delta \tau_{p}$ in the property tax rate, applied to the city's current tax base $M V_{0}$, yields an initial increase in property tax revenues of $\Delta T_{p}=\Delta \tau_{p} \cdot M V_{0}$, which is then available for public spending. For this small rate increase, market values will then change by $\Delta M V \simeq[(v \Phi-1) / r] \Delta \tau_{p} \cdot M V_{0}$. Thus

$$
v \Phi-1 \simeq \frac{\Delta M V}{\Delta \tau_{p}} \cdot \frac{r}{M V_{0}} .
$$

Knowing $M V_{0}$ and $r$, and using our econometric estimates of $\Delta M V / \Delta \tau_{p}$, we can estimate $v \Phi-1$, and finally $v \Phi$ as a measure of the annual gross benefits of a marginal dollar of taxation to a local property owner.

For the estimates reported here we use the average real rate of interest over our sample period, equal to $3.00 \%$ (since $\tau_{p}$ is measured as a percentage in our regressions, so too must $r$ ), $M V_{0}$ is set at the sample mean market value for each city, and $\Delta M V / \Delta \tau_{p}$ is set equal to the estimated impact effect on the city tax property tax base of increases in $\tau_{p}$. From table 1, for Houston, $\Delta M V / \Delta \tau_{p}=-11,995$ (s.e. $=$ 5,488 ); for Minneapolis, $-2,485$ (s.e. $=865$ ); for New York City, $-10,532$ (s.e. $=1,488$ ); and for Philadelphia, $-3,080$ (s.e. $=615)$. Upon substitution, we obtain $v \Phi=0.21$ (s.e. $=0.36$ ) for Houston; $v \Phi=0.77$ (s.e. $=0.08$ ) for Minneapolis; $v \Phi=-0.16$ (s.e. $=.16$ ) for New York City; and $v \Phi=0.43$ (s.e. $=0.11$ ) for Philadelphia. The null hypothesis that the marginal dollar of local property taxation over our sample period generated a dollar of compensating gross benefits - that is, $v \Phi=1$-is clearly rejected for all four of our sample cities, strikingly so for New York City. Likely recipients of the marginal dollar of city spending other than city property owners include low-income 
households, public employees through inefficient labor contracts, and, in the case of New York City, prior city residents and retired public employees because of city deficits and underfunded pensions from the 1960s and early 1970s being repaid over most of our sample period as Municipal Assistance Corporation (MAC) debt. ${ }^{12}$

Table 2 provides estimates of the effects of own tax rates on the tax base for sales and income taxation in New York City and on gross receipts and wage taxation in Philadelphia, again controlling for annual growth via the constant term, and for $\Delta U E, \Delta Z$, and $\triangle C R I M E .{ }^{13}$ For New York City, increases in both the city's sales $\left(\tau_{s}\right)$ and income tax rates $\left(\tau_{w}\right)$ have statistically and quantitatively important negative effects upon their respective tax bases. Lagged effects are not significant economically. The estimated elasticities of base with respect to changes in own rates range from -0.47 to -0.52 for New York sales taxation and from -0.46 to -0.53 for New York City income taxation; see table 2. Recessionary swings in the national macroeconomy $(\Delta U E)$ lower New York's sales and income tax bases, though the effects are not quite statistically significant. Changes in the rate of national crime $(\triangle C R I M E)$ and exogenous aid $(\Delta Z)$ have no important effects on the city jobs or sales.

For Philadelphia, increases in the city's gross receipts tax rate $\left(\tau_{x}\right)$ reduce overall business activity in the city. There are no important lag effects. The estimated rateto-base elasticity ranges from -0.19 to -0.27 . As in New York, recessionary swings in the national macroeconomy $(\Delta U E)$ hurt the Philadelphia economy, whereas changes in the national rate of crime $(\triangle C R I M E)$ or federal and state aid to the city $(\Delta Z)$ again have no significant effects. In contrast to New York, however, Philadelphia's wage tax base per resident shows little overall sensitivity to changes in the city's weighted average wage tax rate on residents and nonresidents. The effect is small and always statistically insignificant. This result does not mean the city's wage tax is without economic consequences, however. We show below (table 5) that the small elasticity is the result of two offsetting real side effects: changes in the city's wage tax rate change jobs and population in roughly the same proportions. Thus the wage tax base per resident remains unchanged, even though increases in city wage tax rates significantly reduce the overall size of Philadelphia's economy. ${ }^{14}$

\footnotetext{
${ }^{12}$ For additional evidence consistent with these results for larger samples of other local governments, see Vigdor (1998), Gyourko and Tracy (1989), Glaeser and Kahn (1999), and Haughwout and Inman (2002) Fuchs (1992) and Shefter (1992) provide excellent case studies of New York City's spending during this period.

${ }^{13}$ Again we tested for the possible effects of changes in public service costs $(\Delta c)$, interest rates $(\Delta r)$, and nonresident wages $(\Delta q)$, and again these variables proved statistically insignificant.

${ }^{14}$ In a separate study of Philadelphia's wage tax base, our colleague Richard Voith (2002) uses changes in the city's aggregate wage tax base as the dependent variable and, consistent with our conclusion here, finds
}

Finally, table 3 reports own and cross tax rate impact (one fiscal year) elasticities for New York City and Philadelphia, based upon a first-difference specification including all local tax rates, a constant term, $\Delta U E, \Delta Z$, and $\triangle C R I M E$. Only the tax rate elasticities are reported in table 3. Estimation is by OLS, equivalent to generalized least squares in this case. Estimates of each tax rate's own impact elasticity are similar in magnitude and statistical significance to those reported in tables 1 and 2. The estimated cross elasticities are generally small and always statistically insignificant. In the analysis which follows we focus on own tax rate elasticities only.

\section{Robustness}

We provide two checks of robustness for our core results. The first panel of table 4 presents IV estimates for the effects of $\Delta \tau_{i}$ on $\Delta B_{i}$. Also reported are the $F$-tests for the explanatory power of the instruments from the stage I $\Delta \tau_{i}$ regressions. The results reported in the second panel of table 4 repeat the core OLS estimates for the effects of $\Delta \tau_{i}$ on $\Delta B_{i}$, but now each $\Delta B_{i}$ equation includes, in addition to $\triangle U E, \Delta Z$, and $\triangle C R I M E$, other potentially important economic or policy events thought to impact city tax bases.

For IV estimation, stage I instruments used to identify changes in local rates include exogenous local political events thought to change the players or preferences setting local rates, as well as exogenous state and national fiscal policies thought to change the overall attractiveness of local spending or the relative attractiveness of different local taxes. Valid instruments must be significant determinants of local tax rate changes and also be uncorrelated with changes in the local tax base, except through changes in the local tax rate.

In our four sample cities, property tax rates are decided by local politicians. Instruments used to predict changes in local property tax rates include the local election cycle (Levitt, 1997), unexpected changes in statewide aid to all local governments, changes in the state share of state and local government spending, state-legislated changes in the ratio of residential to commercial property assessment rates (Minneapolis), the increase in minority representation on a city council following the 1980 arrest and conviction of city council members for influence peddling (Philadelphia), a 1977 audit of Mayor Rizzo's pre-election-year budget by the research staff of the Philadelphia Federal Reserve Bank revealing a sizable postelection fiscal deficit (Philadelphia), and the 1985 state-mandated reforms of local business taxation (Philadelphia).

For New York City and Philadelphia, changes in income, sales, wage, and gross receipt tax rates require approval of the state legislature. These rate changes should be viewed as an outcome of a state-city fiscal bargain; it is not uncommon that city requests for rate changes are denied. Instruments

a significant negative effect of tax rate changes on changes in the total tax base. 
TABLE 4.- Sensitivity Analysis

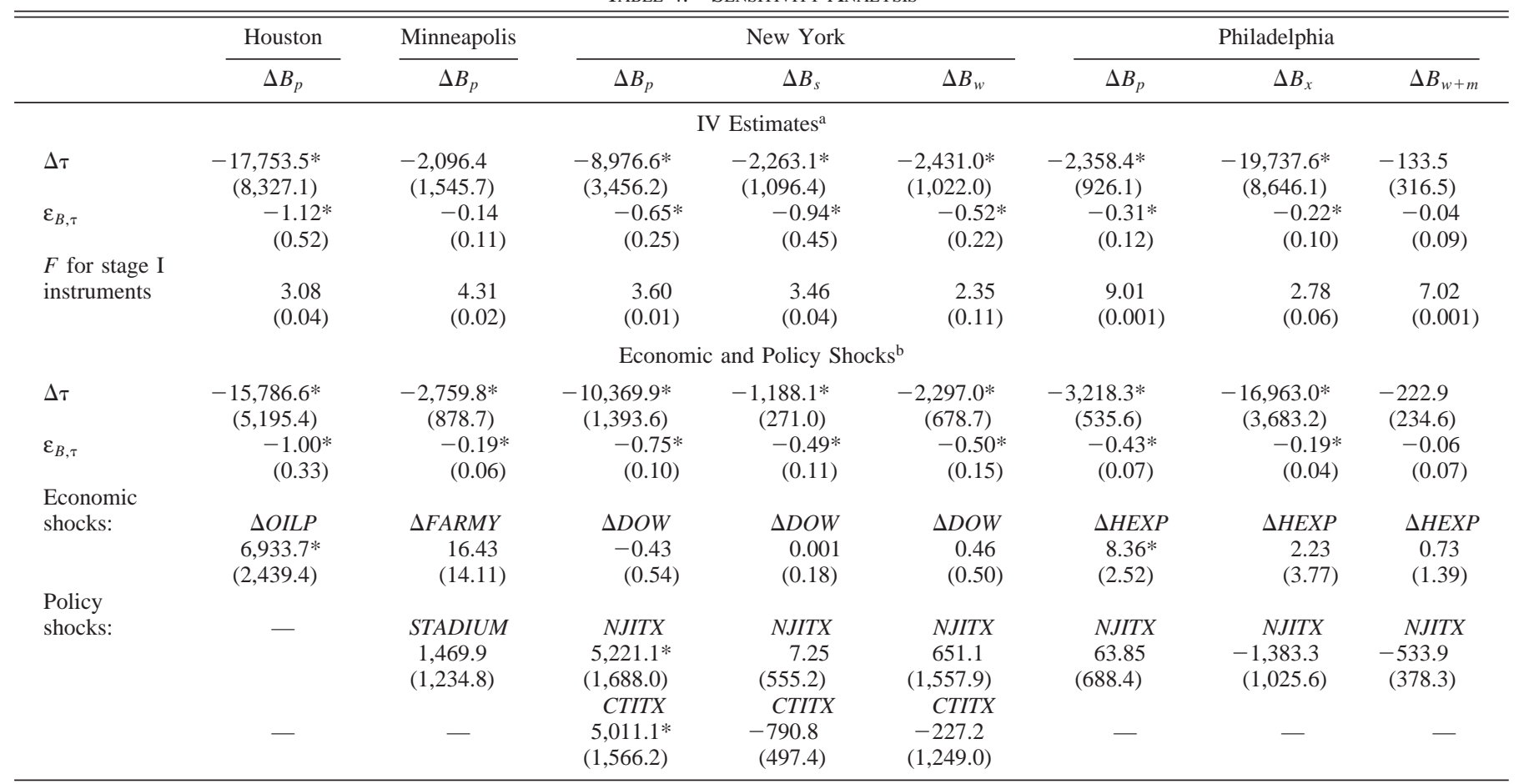

IV estimates based upon the IV estimation of each city's tax rate; see appendix B. The $p$-value for $F$-statistic is in parentheses. The IV equations include $\triangle U E, \triangle C R I M E$, and $\triangle Z$.

${ }^{\mathrm{b}}$ See text for details. All economic and policy shock regressions also include $\triangle U E, \triangle C R I M E$, and $\triangle Z$.

* Coefficient or elasticity's $t$-statistic $\geq 2.00$. Standard errors for each estimated coefficient are reported within parentheses.

used to predict changes in the New York City sales and income tax rates include unexpected statewide aid to all local governments, the passage of the 1986 federal Income Tax Reform Act, and lagged state income tax rates. Instruments used to predict changes in Philadelphia's gross receipts and wage tax rates include the 1977 audit revealing sizable city budget deficits, the 1985 state-mandated reforms of local business taxation, and lagged state income tax rates. See appendix B.

The $F$-tests reported in table 4 show that the instruments as a set work well in predicting changes in local property tax rates but are perhaps less successful in predicting rate changes for New York City income and Philadelphia gross receipts taxation. The new literature on weak instruments cautions that first-stage $F$-statistics should be 3 or larger and ideally have values above 10; see Bound, Jaeger, and Baker (1995, table A.1) and Staiger and Stock (1997). The statistic $(1 / F)$ is an approximate estimate of the finite-sample bias of IV relative to OLS estimators. Although our instruments for property tax rate changes are reasonable by this criterion, our instruments for New York City income tax rates and Philadelphia wage and gross receipts tax rates should be considered weak. When instruments are weak, the IV instruments will fail to correct OLS bias if bias does exist, and indeed may make matters worse if the instruments are even weakly correlated with the errors in the stage II regression (Bound, Jaeger, \& Baker, 1995). This leads us to prefer the IV estimates for property taxation and the original OLS estimates for the New York City sales and income tax base equations and the Philadelphia gross receipts and wage tax base equations. For these OLS estimates we must rely upon an a priori belief that the lagged specification for rates and/or the fact that state, not local, politics determines rates is an appropriate basis for identification of observed rate-to-base effects.

The second panel of table 4 tests the sensitivity of our estimated tax base elasticities to the inclusion of cityspecific, but still exogenous, economic and policy events omitted from our core regressions. For purposes of comparison with tables 1 and 2, the regressions are OLS and continue to include a constant term, $\triangle U E, \Delta Z$, and $\triangle C R I M E$ as regressors. Included as additional exogenous economic determinants of each city's tax base are the annual change in real oil prices $(\triangle O I L P)$ for Houston; the annual change in real farm incomes $(\triangle F A R M Y)$ for Minneapolis; the annual change in the Dow-Jones Industrial Average $(\triangle D O W)$ for New York City; and the annual change in health care expenditures $(\triangle H E X P)$ for Philadelphia. Included as exogenous policy events are (1) state-financed construction of the Metrodome sports stadium and the Minneapolis Convention Center for Minneapolis, represented by an indicator variable (STA$D I U M)$ equal to 1 for the first year of construction, 0 otherwise; and (2) the introduction of state income taxation in New Jersey in FY 1977 (for New York City and Philadelphia) and in Connecticut in FY 1992 (for New York only), measured respectively by indicator variables 
NJITX and CTITX equal to 1 for the fiscal year introducing the tax, 0 otherwise. We know of no comparable exogenous policy events likely to have impacted the Houston economy.

The inclusion of these additional economic and policy event variables in our core OLS regressions does not significantly affect our initial estimates of the rate-tobase elasticities as reported in tables 1 and 2. Also of interest are the effects of the new variables themselves on city tax bases. For two of our cities, Houston and Philadelphia, industry-specific changes in the national economy can make a significant difference to the city tax base. In each case, the primary effect of industry shocks is to change city property values, a result consistent with predictions from a fully specified general equilibrium model of open city economies where swings in the demand for city products are capitalized into the value of city land and structures; see Haughwout and Inman (2001). From table 4, the implied elasticity of Houston's property tax base with respect to changes in the price of oil $(\triangle O I L P)$ is 0.26 (s.e. $=0.09$ ). For Philadelphia the implied elasticity of the city's property tax base with respect to changes in national health care spending $(\triangle H E X P)$ is $0.95($ s.e. $=0.28)$. The tax bases in Minneapolis and New York City are not, however, much affected by our measures of national demand for city outputs. Popular accounts aside, we find no evidence over our 30-year sample period that swings in financial market fortunes as measured by $\triangle D O W$ have much impact on the average value of the New York City tax bases.

What did matter for the New York City tax base were the decisions by its neighboring states of New Jersey and Connecticut to introduce state income taxes. Again, consistent with a general equilibrium specification of taxation in an open city economy, the primary effect is felt through changes in city property values. New York City property values received a one-time boost of about $\$ 5,000 /$ person from its regional competitors' decisions to introduce a state income tax. ${ }^{15}$ Philadelphia property

\footnotetext{
${ }^{15}$ Are these effects too big? An example helps put our estimates in perspective. New Jersey introduced a progressive tax on resident income with rates ranging from $1.5 \%$ to $3 \%$. An average 1977 family considering living in New York City or northern New Jersey had an annual family income of approximately $\$ 40,000$ in 1994 dollars. This family faced a New Jersey state income tax rate of approximately $3 \%$. It could therefore anticipate paying an additional $\$ 1,200 /$ year in taxes, above what it might have paid in FY 1976. Capitalizing this tax increase at a real interest rate of 0.03 per annum implies a maximal increase in the value of New York City land and structures of about $\$ 40,000(=\$ 1,200 / 0.03)$ per parcel, or about \$13,333/resident (assuming three residents per family). The estimated increase in value is $\$ 5,221 /$ resident following the introduction of the New Jersey income tax. New York City capitalization is therefore 37\% of maximal capitalization. Northern New Jersey property values no doubt fell as well to restore residential equilibrium. A similar calculation for the introduction of the Connecticut income tax gives a similar result. The 1991 Connecticut income tax rate was $1.5 \%$ but was understood to be about to rise to $4 \%$ in 1992. For a New York City or Connecticut family with the average income of $\$ 55,000$ (1994 dollars) we use the expected tax rate of $4 \%$ and an implied tax burden of $\$ 2,200 /$ year. Capitalized at
}

values were not impacted by the New Jersey decision, however.

We performed one final robustness check, whose results are not shown here but which seems worth mentioning briefly. In recent years, much has been made of America's new urban leadership as a catalyst for economic change. Our sample includes the mayoral terms of two of the most often heralded "new" urban leaders: Mayor Giuliani of New York City and Mayor Rendell of Philadelphia. Perhaps the favorable tax rate changes in our sample are correlated with the terms of these particularly charismatic and effective mayors, with the result that the estimated changes in tax base are due to mayoral leadership style rather than fiscal policy per se. We tested this possibility by including in our core specifications an indicator variable equal to 1 for each year of these mayors' tenures, 0 otherwise. The mayoral variables were always statistically insignificant, and our core estimates of the rate-to-base elasticities were unaffected. We conclude that it is the mayor's fiscal and economic policies and not their personalities that affect local economies.

\section{Taxes and City Jobs}

As additional evidence for the effects of city taxes on city tax base, table 5 provides estimates of the effects of changes in city taxes and associated public spending on city jobs for New York City and Philadelphia, the two cities in our sample for which annual employment data are available. Results are presented for changes in each city's share of national total employment, of national manufacturing employment $(=$ manufacturing + construction + communications + public utility + transportation employment), and of national service employment (= finance-insurance-real estate + retail + wholesale + services + federal and state government employment). Initial estimates showed that of all our city tax rates, only changes in New York City's income tax rate (measured as the top marginal rate) and Philadelphia's wage tax rate (measured as the weighted average of resident and nonresident rates) were statistically significant and quantitatively important determinants of each city's shares of national jobs. OLS results are reported in table 5; IV results are similar (though less precise) and are available upon request.

In 1970 New York City had 5.28\% of the nation's jobs; today (2001) the city's share is $2.88 \%$. As demonstrated by the negative constant terms in each of New York City's employment share equations there has been a

0.03 per annum, this implies an increase in value of city land and structures of $\$ 73,333$, or $\$ 24,444 /$ resident (assuming three residents pe family). The estimated increase in value is $\$ 5,011 /$ resident following the introduction of the Connecticut income tax. New York City capitalization is estimated to be $22 \%$ of maximal capitalization. Again, maximal capitalization is a likely upper bound to the potential changes in New York City property values; for Connecticut provided state services and local aid with the additional state revenues, and western Connecticut property values also adjusted downward. 
TABLE 5.-TAXATION AND JOB LOCATION ${ }^{\mathrm{a}}$

\begin{tabular}{|c|c|c|c|c|c|c|}
\hline & \multicolumn{6}{|c|}{$\triangle J O B S H A R E$} \\
\hline & \multicolumn{3}{|c|}{ New York } & \multicolumn{3}{|c|}{ Philadelphia } \\
\hline & Total & Manufacturing & Services & Total & Manufacturing & Services \\
\hline Constant & $\begin{array}{c}-.000701 \\
(.000404)\end{array}$ & $\begin{array}{c}-.000698 * \\
(.000191)\end{array}$ & $\begin{array}{r}-.000890 \\
(.000577)\end{array}$ & $\begin{array}{c}-.000244 * \\
(.000057)\end{array}$ & $\begin{array}{c}-.000248 * \\
(.000092)\end{array}$ & $\begin{array}{c}-.000272 * \\
(.000056)\end{array}$ \\
\hline$\Delta \tau_{w}, \Delta \tau_{w+m}$ & $\begin{array}{c}-.000525^{*} \\
(.000184)\end{array}$ & $\begin{array}{r}-.000620 * \\
(.000227)\end{array}$ & $\begin{array}{r}-.000450 \\
(.000232)\end{array}$ & $\begin{array}{c}-.000262 * \\
(.000100)\end{array}$ & $\begin{array}{r}-.000101 \\
(.000127)\end{array}$ & $\begin{array}{c}-.000290 * \\
(.000111)\end{array}$ \\
\hline$\Delta \tau_{w}(-1), \Delta \tau_{w+m}(-1)$ & $\begin{array}{c}-.000568 * \\
(.000195)\end{array}$ & $\begin{array}{c}-.000701 * \\
(.000235)\end{array}$ & $\begin{array}{r}-.000415 \\
(.000247)\end{array}$ & $\begin{array}{c}-.000299 * \\
(.000088)\end{array}$ & $\begin{array}{c}-.000244^{*} \\
(.000117)\end{array}$ & $\begin{array}{r}-.000288 * \\
(.000089)\end{array}$ \\
\hline$\Delta \tau_{w}(-2), \Delta \tau_{w+m}(-2)$ & $\begin{array}{r}-.000361 \\
(.000183)\end{array}$ & $\begin{array}{c}-.000622 * \\
(.000226)\end{array}$ & $\begin{array}{l}.000051 \\
(.000231)\end{array}$ & $\begin{array}{r}-.000087 \\
(.000073)\end{array}$ & $\begin{array}{c}-.000184^{*} \\
(.000089)\end{array}$ & $\begin{array}{r}-.000001 \\
(.000008)\end{array}$ \\
\hline D.W. & 1.36 & 1.82 & 1.53 & 1.91 & 2.00 & 2.05 \\
\hline $\bar{R}^{2}$ & 0.767 & 0.620 & 0.701 & 0.580 & 0.625 & 0.428 \\
\hline$\varepsilon_{\text {Share }, \tau}^{\text {SR }}$ & $-0.06^{*}$ & $-0.10^{*}$ & -0.04 & $-0.14 *$ & -0.07 & $-0.14^{*}$ \\
\hline (s.e.) & $(0.02)$ & $(0.04)$ & $(0.02)$ & $(0.06)$ & $(0.09)$ & $(0.05)$ \\
\hline$\varepsilon_{\text {Share }, \tau}^{\mathrm{LR}}$ & $-0.16^{*}$ & $-0.31 *$ & -0.09 & $-0.36^{*}$ & -0.39 & $-0.29^{*}$ \\
\hline (s.e.) & $(0.05)$ & $(0.08)$ & $(0.06)$ & $(0.11)$ & $(0.21)$ & $(0.10)$ \\
\hline
\end{tabular}

a Each $\triangle J O B S H A R E$ OLS equation includes $\triangle U E, \triangle C R I M E$, and $\triangle Z$ as independent variables. Standard errors for each estimated coefficient are reported within parentheses. D.W. is the Durbin-Watson test statistic for serial correlation. $\bar{R}^{2}$ is the coefficient of determination corrected for degrees of freedom. The elasticity of city job share with respect to changes in the city income or wage tax is calculated for the first year of the new tax rate as the impact elasticity $\left(\varepsilon_{\text {Share, }, \text { }}^{\mathrm{SR}}\right)$ and as the longer-run elasticity after three fiscal years of the new tax rate $\left(\varepsilon_{\text {Share, } \tau}^{\mathrm{LR}}\right)$. All elasticities are calculated at sample means.

* Coefficient's or elasticity's $t$-statistic $\geq 2.00$.

steady secular trend away from city jobs. Compounding the secular loss in job shares have been increases in the city's income tax rates over the past thirty years, rising from a top marginal rate of $2.00 \%$ to $4.66 \%$ in 1994 , then falling in a sequence of three reductions to $3.592 \%$ by 2001 , the last year in our sample. The estimates in table 5 show a statistically significant negative effect of these rate changes on the city's share of national jobs, reducing the city's job share when rates rise and increasing it when rates fall. Simulating the path of city jobs using the estimated equation in table 5 shows New York City lost 331,338 jobs by 2001 because of these increases in city income tax rates, roughly $8.7 \%$ of total city jobs in 2001 . The loss of jobs would have been much larger-487,913 jobs-had the city not cut tax rates beginning in $1994 .{ }^{16}$ Because the city is still on the rising portion of its income tax revenue hill, however, the approximately 150,000 jobs saved because of the rate cut did cost the city income tax revenues. For New York City, our results suggest the present value of lost city revenues for each job created will be approximately $\$ 146,233 /$ job. ${ }^{17}$

\footnotetext{
${ }^{16}$ To calculate the contribution of New York City tax increases to the decline in the city's share of national jobs, we used the results reported in table 5 to simulate a predicted path of the city's job share, first with and then without the actual tax rate changes from 1971 to 2001. The difference between the two job share paths is our estimate of the effect of city tax rate changes on the city's employment share. The predicted job shares are then multiplied by the national total number of jobs in 2001 to calculate the city total number of jobs with and without tax rate changes.

${ }^{17}$ The marginal revenue costs of a new job can be estimated as $\Delta$ Revenuel $\Delta J$ obs, where $\Delta$ Revenue $=$ Revenue $\cdot\left(1+\varepsilon_{B, \tau}\right)(\Delta \tau / \tau)$ and where $\Delta$ Jobs $=J o b s \cdot \varepsilon_{N+M, \tau} \cdot(\Delta \tau / \tau)$. Since we use the baseadjusted elasticities to estimate the effects of rate reductions on revenues, the estimates of revenue costs will be net of the additional revenues made available by the new jobs. Using New York City's 2001 values for income tax revenues $(=\$ 608 /$ resident $)$ and city jobs $(=0.46$ jobs/resident $)$, and the OLS estimates for $\varepsilon_{B, \tau}(=-0.47$ : table 2$)$ and $\varepsilon_{N+M, \tau}(=-0.16$ : table 5 ), we estimate the annual revenue loss per new city job to be $-\$ 4,378 /$
}

Philadelphia's share of national jobs has declined from $1.24 \%$ in 1971 to $0.52 \%$ by 2001 . Here too the negative and significant constant term in the share equations shows the secular trend in jobs away from the Philadelphia economy. Over our sample period, the city's weighted average wage tax rate rose from $3.00 \%$ in 1971 to a peak of $4.766 \%$ in 1995 . Since 1996 , the wage tax rate has been reduced to the current (2001) weighted average rate of $4.384 \%$. The estimates in table 5 show a statistically significant negative effect of these rate changes on the city's job share. ${ }^{18}$ We estimate that between 1971 and 2001 Philadelphia lost 172,889 jobs because of the increase in city wage tax rates; without the wage tax rate cuts begun in FY 1996 the loss (again, in 2001) would have been instead 202,291 jobs. ${ }^{19}$ By our

job. Because the local tax cut must be permanent to be credible, we calculate the present value of all future annual revenue losses as the cost of a job created. Assuming a 3\% real interest rate, this equals $\$ 146,233 / \mathrm{job}$ $(=\$ 4,387 / 0.03)$.

18 The contrast between the strong negative effect of Philadelphia's wage tax rate on city jobs shown in table 5 and that same rate's insignificant effect on the city's wage tax base per resident shown in table 2 deserves comment. The explanation for these contrasting results lies in the negative effect that a higher city wage tax rate also has on city population. A precise estimate of the effects of city taxes on city population is impossible because we lack an accurate annual population series, but decade-todecade changes in Philadelphia's share of the national population regressed on a constant term and on decade-to-decade changes in the city's wage tax rate show a significant negative elasticity of population with respect to tax rates: -0.27 (s.e. $=0.17$ ). Given that the estimated elasticity of Philadelphia jobs with respect to the wage tax rate is -0.36 (table 5), we see both jobs and residents leave the city at roughly the same rate as the city wage tax rate rises. Philadelphia's wage tax base per resident is therefore unchanged (table 2), though the city and its economy are both significantly smaller (table 5).

${ }^{19}$ To calculate the contribution of Philadelphia tax increases to the decline in the city's share of national jobs, we first used the results of table 5 to simulate the path of the city's job share for the actual rate changes between 1971 and 2001. We then simulated the path of the city's job share, holding the tax rate fixed at its 1971 value $(3.00 \%)$. The difference of the two series provides our estimate of the effect of tax rate changes on the 
measures, the programmed reduction in city wage tax rates begun by Mayor Rendell in 1996 and continued under the current Mayor Street saved the city 29,402 jobs. Again, since the city is on the rising portion of its wage tax revenue hill, these rate reductions lead to a fall in city revenue. We estimate the present-value revenue loss per job created to be $\$ 133,583 .{ }^{20}$

Should New York City and Philadelphia use income and wage tax cuts to create jobs? While our estimates of the present value revenue costs of each job created are large, city officials must appreciate that these revenue losses are not the economic costs of creating new jobs in the city through tax cuts. City revenues lost are private incomes gained, in this case by city residents and firms. The true economic costs of city job creation using tax cuts equals the marginal net benefit of a dollar of city spending lost because of loss of city revenues. Our estimates in section IIIB above suggest that the marginal net benefits of city spending for property owners in New York and Philadelphia are well below 1, and for all city residentsproperty owners, city employees, and lower-income households-probably no larger than 1 . If so, then incremental cuts in New York and Philadelphia income and wage tax rates create new jobs in the city at no net economic cost to the average city resident. The end result is a smaller public sector, but a larger, and arguably more productive, private city economy; see Inman (2003).

\section{Local Revenue Hills}

Figure 1 presents each city's revenues hills. Estimates of property tax revenue hills use the IV estimates of each city's $\Delta B_{p}$ equation, controlling for $\Delta U E, \Delta Z, \triangle C R I M E$, and each city's significant economic and policy events. Estimates of New York City's sales and income tax revenue hills use OLS estimates of the city's $\Delta B_{s}$ and $\Delta B_{w}$ equations, controlling for $\triangle U E, \triangle Z$, and $\triangle C R I M E$. Estimates of Philadelphia's gross receipts and wage tax revenue hills use OLS estimates of the city's $\Delta B_{x}$ and $\Delta B_{w+m}$ equations, again controlling for $\Delta U E$, $\Delta Z$, and $\triangle C R I M E$. Each hill is evaluated for current (FY 2001) city tax rates and revenues; all dollar figures are reported in 1994 dollars. ${ }^{21}$ Four conclusions seem evident.

city's job share. The predicted tax shares are then multiplied by the total number of national jobs to calculate the total number of city jobs with and without tax rate changes.

20 The revenue cost of a marginal job restored from the 2001 tax cuts can be estimated - as in footnote 17 above-by $\Delta$ Revenuel $\Delta J$ obs, where $\Delta$ Revenue $=$ Revenue $\cdot\left(1+\varepsilon_{B, \tau}\right) \cdot(\Delta \tau / \tau)$ and where $\Delta$ Jobs $=$ Jobs $\varepsilon_{N+M, \tau} \cdot(\Delta \tau / \tau)$. Using Philadelphia's 2001 values for wage tax revenues (\$706/resident) and city jobs $(0.46$ jobs/resident $)$ and the OLS estimates for $\varepsilon_{B, \tau}(=-0.06$ : table 2$)$ and $\varepsilon_{N+M, \tau}(=-0.36$ : table 5), we estimate the annual revenue loss per new city job created to be $-\$ 4,007$. The present value of these annual revenue losses equals $\$ 133,583 /$ job $(=\$ 4,007 / 0.03)$.

${ }^{21}$ Each revenue hill is estimated by the relationship Revenue $=\tau_{0}$. $B_{0}+\Delta \tau \cdot B_{0}+\tau_{0} \cdot \Delta B+\Delta \tau \cdot \Delta B$, where $\tau_{0}$ and $B_{0}$ are the actual tax rates and tax base for the last year of our sample, $\Delta \tau$ is the change in tax rate from $\tau_{0}$ to each new tax rate along the horizontal axis, and $\Delta B$ is the predicted equilibrium change in base for each $\Delta \tau$ using each tax's estimated $\Delta B$ equation. Finally, to estimate New York City's income tax
First, each of our cities can raise additional revenues. With the exception of Houston, higher tax revenues require higher tax rates and this means lower tax bases. Because Houston is estimated to be beyond the peak of its property tax revenue hill, a lower property tax rate is required to increase city revenues. To maximize revenues, Houston's property tax rate should be reduced from $2.54 \%$ to $2.1 \%$. With this cut in the city's property tax rate, the city's equilibrium property tax base per resident increases from $\$ 40,120 /$ resident to $\$ 50,383 /$ resident. This increase is sufficient to offset the rate reduction. The city raises an additional $\$ 40 /$ resident in property tax revenues.

In contrast to our other three sample cities, Minneapolis is positioned well down the rising portion of its revenue hill. The city has the potential to more than double its property tax revenues per resident if it wishes. The required increase in property tax rates will have a negative effect on the city's tax base, however. Were city officials to move from today's rate of $3.22 \%$ to the revenue-maximizing rate of $12.5 \%$ (we caution that this rate is well outside our sample range), the value of the city's property tax base is predicted to decline by $42 \%$ from its current (2001) value of $\$ 47,308 /$ resident to a new equilibrium base of $\$ 27,213 /$ resident.

New York City's best sources for new revenues are its property and sales taxes. Moving to the top of the city's income tax revenue hill through a proportional increase in income tax rates, represented in figure 1 as an increase in the current (2001) top marginal tax rate of $3.59 \%$ to the peak rate of $5.80 \%$, will raise only $\$ 35 /$ resident in additional revenues. Moving to the peak of the city's property tax revenue hill by increasing the city's current (2001) property tax rate from $2.497 \%$ to $3.3 \%$ raises an additional $\$ 53 /$ resident in revenues, but as a consequence, average city property values fall by $20 \%$, from $\$ 34,590 /$ resident to $\$ 27,751 /$ resident. The city's sales tax offers the greatest potential for new revenues. Increasing the sales tax rate from the current (2001) rate of $4.0 \%$ to the peak rate of $6.2 \%$ raises an additional $\$ 56 /$ resident, though city sales are estimated to fall by $26 \%$ from their 2001 level of $\$ 9,634 /$ resident to $\$ 7,102 /$ resident.

Figure 1 shows Philadelphia to have an unlimited ability to raise revenues per resident through the city's wage tax, but, as noted in section IV above, an increase in the city's wage tax rate means proportional losses of city jobs and residents. There is now a strong political consensus within the city to continue with at least the modest scheduled cuts in wage tax rates. Additional

revenue hill, $\tau_{0}$ and $\Delta \tau$ are the tax rates for the average-income household; however, $\Delta B$ is estimated from changes in the top marginal rate. For our sample period, the revenue-weighted effective average tax rate is linked to the top statutory marginal rate as follows: effective average rate $=$ $0.3225 \times$ (top statutory marginal rate). The top marginal rates is reported on the horizontal axis of figure 1 for the panel labeled New York City, Income Tax. 
Figure 1.-City Revenue Hills

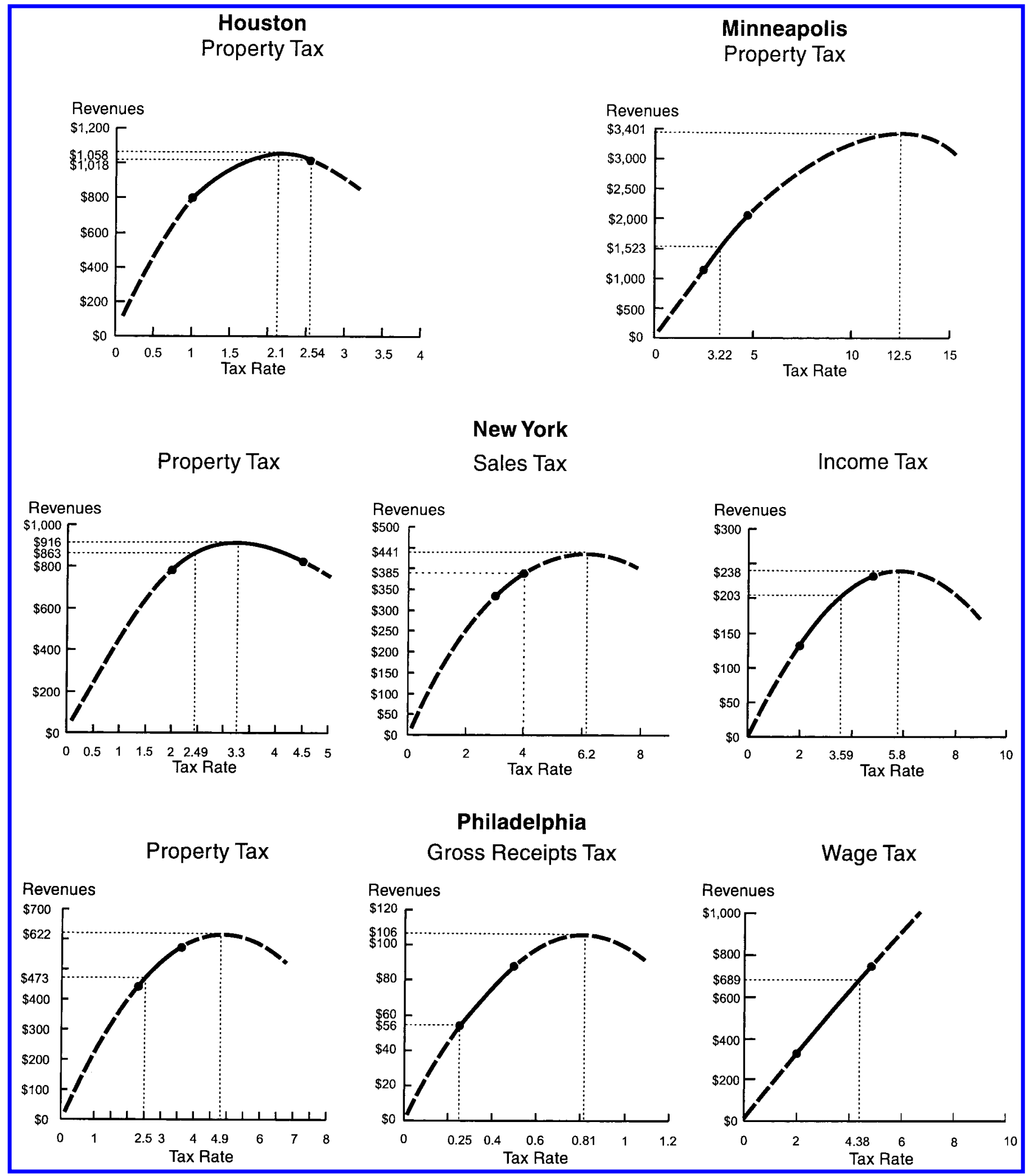

The solid lines between dashes represent the portion of the hill which spans the range of our data for city tax rates; the long dashed portions of each hill are projections beyond the sample's range. Dotted lines relate tax rates to revenues, first for the current (2001) tax rate, and then for the revenue-maximizing rate to illustrate each tax's revenue potential. 
revenues of $\$ 149 /$ resident are available from the increases in the city property tax rate from today's (2001) rate of $2.50 \%$ to the peak rate of $4.90 \%$. Average property values will fall from $\$ 18,914 /$ resident to $\$ 12,685 /$ resident, however. The city's gross receipts tax rate can raise an additional $\$ 50 /$ resident from increasing current (2001) rates from $0.25 \%$ to $0.81 \%$, but gross sales will decline by $40 \%$ from $\$ 22,648 /$ resident to $\$ 13,515 /$ resident.

Second, in this period of tight local budgets brought on by the current recession, Houston and New York City may have difficulty covering anticipated FY 2004 deficits with tax increases-New York City particularly. Deficits in this discussion are from current city budgetary estimates for FY 2004, deflated to 1994 dollars for comparison with our revenue projections in figure 1. The predicted FY 2004 deficit for Houston is \$65/resident; figure 1 shows that the city's currently unused taxing capacity is \$40/resident. The predicted FY 2004 deficit for Minneapolis is $\$ 108 /$ resident; figure 1 shows that the city's currently unused taxing capacity is well over $\$ 1000 /$ resident. The predicted FY 2004 deficit for New York City is $\$ 620 /$ resident; the sum of the revenue capacities of the city's three major taxes is $\$ 144 /$ resident. The predicted FY 2004 deficit for Philadelphia is \$126/resident, a gap which can be covered by the $\$ 199 /$ resident taxing capacity now available from property and gross receipts taxation. Though the tax option is available to Houston, Minneapolis, and Philadelphia to cover most, if not all, of their anticipated deficits, New York can only close a small portion of its deficit gap-we estimate no more than $23 \%$ in equilibrium-with tax increases. Significant spending cuts or substantial increases in federal and/or state assistance will be needed for New York City to return to permanent fiscal balance. ${ }^{22}$

\footnotetext{
${ }^{22}$ In the winter of 2003, New York City faced an estimated deficit of \$6.4 billion in current 2003 dollars for its coming 2004 fiscal year. To close the gap, the city approved a budget which included $\$ 1.7$ billion in spending cuts, the reallocation of a $\$ 0.8$ billion surplus from FY 2003 budget forward to FY 2004 , and $\$ 2.9$ billion in estimated additional tax revenues, to be collected from higher property, income, and sales taxation. To close the remaining \$1 billion budget gap, the city received an additional $\$ 1$ billion in state fiscal assistance. (Source: Mr. Frank Posillico of the New York City Independent Budget Office staff.) In making its revenue projections from the proposed rate increases, the city used a static (constant base) analysis. Our dynamic (base-adjusted) analysis suggests the initial estimates may be optimistic, at least in equilibrium. Our best-case estimates suggest the city can raise at most $\$ 2.25$ billion rather than the originally projected $\$ 2.9$ billion $-\$ 1.7$ billion from a one-time, lump-sum levy on property owners, $\$ 0.208$ billion from the increase in income tax rates, and finally, $\$ 0.341$ billion from the joint rate increase and base expansion in sales taxation. If our dynamic analysis is correct, New York City will continue to face an equilibrium budget deficit of at least \$650 million in current (2003) dollars. Three comments regarding our tax analysis are in order. First, and perhaps most importantly, the original estimate of an additional $\$ 1.7$ billion in property tax revenues assumes the proposed $18.5 \%$ rate increase will be temporary and can be removed before property tax bases are reassessed. If property rates cannot be lowered-and our analysis suggests this will be the case without additional major cuts in city spending - then the one-time increase becomes permanent, legally required reassessments to market values will occur, and property bases will decline, ceteris paribus. If so, the equilibrium increase in property tax revenues must
}

Third, there is little long-term fiscal relief for our sample cities from staying the course. Expected annual growth in tax revenues per resident can be estimated as current (FY 2001) city tax rates times the constant term from each city's $\Delta B_{i}$ equations, then summed over all taxes. Estimated annual increases in city revenues equal $\$ 25 /$ resident (s.e. $=$ $\$ 17$ ) for Houston, $\$ 30 /$ resident (s.e. $=\$ 8$ ) per year for Minneapolis, $\$ 2 /$ resident (s.e. $=\$ 13$ ) per year for New York City, and $-\$ 8 /$ resident $($ s.e. $=\$ 9$ ) per year in Philadelphia. Economic growth alone is unlikely to provide much longterm fiscal relief for our sample cities. The revenue hills in figure 1 are stable in real terms.

Fourth, long-term structural shifts in national aggregate demand towards core economic activities may be able to ease city fiscal pressure in two of our cities, Houston and Philadelphia. But the shifts must be large and permanent. A permanent 1-standard-deviation increase in oil prices (equal to $\$ 12.60 /$ barrel with respect to our sample mean of $\$ 20$ / barrel) adds $\$ 4,368 /$ resident to Houston's property tax base $\left(=\Delta O I L P \quad \partial B_{p} / \partial O I L P=(\$ 12.60 / \$ 20) \times 6,934\right.$; see table 4) and $\$ 109 /$ resident per year to Houston revenues using the city's current tax rate $(=0.025 \times \$ 4,368)$. A permanent 1-standard-deviation increase in national health spending of \$996/person will increase Philadelphia's property tax base (the only significant effect) by $\$ 8,327 /$ resident $\left(=\Delta H E X P \partial B_{p} / \partial H E X P=\$ 996 \times 8.36\right.$; see table 4$)$ and the city's property tax revenues by $\$ 208 /$ resident evaluated at current tax rates $(=0.025 \times \$ 8,327)$.

\section{Conclusions}

Understanding the equilibrium effects of local taxation on the local private economy is important for elected city leaders, urban policy analysts, and academic economists alike. The analysis here offers useful lessons for each.

First, elected city officials must learn the reality of their local revenue constraints. A city's revenue capacity is limited by the mobility of its residents and firms. Three of our cities-Houston, New York City, and Philadelphia-seem to have nearly exhausted that capacity. Barring permanent and significant structural shifts in national demand toward our cities' outputs, city revenue

be reduced from the original static estimate of $\$ 1.7$ billion to a base-adjusted, equilibrium estimate of $\$ 0.560$ billion. This adjustment adds $\$ 1.14$ billion to our estimates of the city's structural deficit, now totaling $\$ 1.79(=\$ 0.650+$ $\$ 1.14$ ) billion. Further, the $18.5 \%$ increase in property tax rates will place the city at the top of its equilibrium property tax revenue hill. Second, our estimates of the dynamic effects of lagged tax rates on the tax base (tables 1 and 2) show that the estimated equilibrium deficit will occur relatively quickly, within 1 to 2 fiscal years. Third, an expanding private economy-say, one which succeeds in lowering the national unemployment rate from the current $6 \%$ to a full-employment $4 \%$-will help the city's income and sales tax bases (table 2), but not enough to close the estimated equilibrium budget gap and almost certainly not enough to allow the city to lower its tax rates back to their FY 2003 levels, as Mayor Bloomberg hopes. There is no evidence that an accelerating stock market adds significantly to the city's income tax base (table 4). City taxpayers should treat the new FY 2004 rates as permanent, unless of course, deeper spending cuts or more state aid is forthcoming. 
hills are likely to remain fixed in real terms. Holding city spending to the rate of inflation therefore seems essential for Houston and Philadelphia. New York City will have to make significant real spending cuts to avoid continued future deficits. Only Minneapolis can raise significant new revenues from taxation.

Second, for urban policy analysts our results reveal a fundamental tension between the interests of city public employees, poor households within the city, and city taxpayers. Tax increases unmatched by tax-financed, compensating service benefits for taxpayers-whether property owners, consumers, or firms-will drive those taxpayers from the city. Property values fall, business sales decline, and the city's job base shrinks. To protect city economies, a dollar of taxes paid must be matched by a compensating dollar of public service benefits. Our evidence suggests this is not now the case for our sample cities, even for Minneapolis.

Third, for our academic colleagues we have offered an example of how one might specify and then estimate governmental revenue hills- "Laffer curves"-based upon a fully specified general equilibrium model of fiscal policy in an open economy. The general equilibrium model presented in Haughwout and Inman $(2001,2002)$ gives the needed structural interpretation. We have shown separately that simulated revenue hills from our structural model calibrated to the Philadelphia economy map closely the estimated curvature of the revenue hills for Philadelphia presented in figure 1; see Haughwout and Inman (2001). Estimated revenue hills also provide the needed budget constraint for any structural analyses of the political economy of local fiscal choice. We view our work here as a complement to the recent research of Epple, Romer, and Sieg (2001); they specify and estimate a model of local fiscal choice, given the local revenue hill. We have specified and estimated the revenue hill, given local fiscal choice. A fully specified structural model of local finance will join these efforts.

\section{REFERENCES}

Bartik, Timothy, Who Benefits from State and Local Economic Development Policies? (Kalamazoo, MI: Upjohn Institute, 1991).

Bound, John, D. A. Jaeger, and R. M. Baker, "Problems with Instrumental Variables Estimation When the Correlation between Instruments and the Endogenous Explanatory Variable is Weak," Journal of the American Statistical Association 90 (June 1995), 443-450.

Brueckner, Jan, "A Test for Allocative Efficiency in the Local Public Sector," Journal of Public Economics 19 (December 1982), 311-331.

Cullen, Julie, and Steven Levitt, "Crime, Urban Flight, and Consequences for Cities," this REVIEW, 81 (May 1999), 159-169.
Desai, Mihar, C. Fritz Foley, and James Hines, "Chains of Ownership, Regional Tax Competition, and Foreign Direct Investment," NBER working paper no. 9224 (2002).

Epple, Dennis, Thomas Romer, and Holger Sieg, "Interjurisdictional Sorting and Majority Rule: An Empirical Analysis," Econometrica 69 (November 2001), 1437-1466.

Feld, Lars, and Gebhard Kirchgassner, "The Impact of Corporate and Personal Income Taxes on the Location of Firms and on Employment: Some Panel Evidence for the Swiss Cantons," Journal of Public Economics 87 (January 2003), 129-156.

Fuchs, Ester, Mayors and Money: Fiscal Policy in New York and Chicago (Chicago: University of Chicago Press, 1992).

Glaeser, Edward, and Matthew Kahn, "From John Lindsay to Rudy Giuliani: The Decline of the Local Safety Net?" Federal Reserve Bank of New York: Economic Policy Review 5:3 (1995), 117-132.

Goolsbee, Austan, and Edward Maydew, “Coveting thy Neighbor's Manufacturing: The Dilemma of State Income Apportionment," Journal of Public Economics 75 (January 2000), 125-144.

Gyourko, Joseph, and Joseph Tracy, "Local Public Sector Rent-Seeking and Its Impact on Local Land Values," Regional Science and Urban Economics 19 (August 1989), 493-516.

Haughwout, Andrew, and Robert Inman, "Fiscal Policy in an Open City with Firms and Households," Regional Science and Urban Economics 31 (April 2001), 147-180. , and Robert Inman, "Should Suburbs Help Their Central City?" Brookings-Wharton Papers on Urban Affairs (2002), 45-94.

Hines, James, "Altered States: Taxes and the Location of Foreign Direct Investment in America," American Economic Review 86 (December 1996), 1076-1094.

Inman, Robert, "The Local Decision to Tax: Evidence from Large U.S. Cities," Regional Science and Urban Economics 19 (August 1989), $455-491$.

, "How to Have a Fiscal Crisis: Lessons from Philadelphia," American Economic Review, Papers and Proceedings 85 (May 1995), 378-383. , "Should Philadelphia's Suburbs Help Their Central City?" Business Review: Federal Reserve Bank of Philadelphia (June 2003).

Levitt, Steven, "Using Electoral Cycles in Police Hiring to Estimate the Effect of Police on Crime," American Economic Review 87 (June 1997), 270-290.

Mark, Stephen, Theresa McGuire, and Leslie Papke, "The Influence of Taxes on Employment and Population Growth: Evidence from the Washington D.C. Metropolitan Area," National Tax Journal 53 (March 2000), 105-124.

Rich, Robert, and Jennie Raymond, "Oil and the Macroeconomy: A Markov State-Switching Approach," Journal of Monev, Credit, and Banking 29 (May 1997), 193-213.

Roback, Jennifer, "Wages, Rents, and the Quality of Life," Journal of Political Economy 90 (December 1982), 1257-1278.

Rosen, Sherwin, "Wage-Based Indexes and the Quality of Life" (pp. 74-104), in P. Mieszkowski and M. Straszheim (Eds.), Current Issues in Urban Economics (Baltimore: Johns Hopkins University Press, 1979).

Shefter, Martin, Political Crisis, Fiscal Crisis: The Collapse and Revival of New York City (New York: Columbia University Press, 1992).

Staiger, Douglas, and James Stock, "Instrumental Variables Regression with Weak Instruments," Econometrica 65 (May 1997), 557-585.

Vigdor, Jacob, "Was Tiebout Wrong? Local Taxes and the Growth of Cities," Harvard University working paper (1998).

Voith, Richard, "Philadelphia City Tax Structure and the Metropolitan Economy," Research Report for the Pennsylvania Economy League (November 2002). 
THE REVIEW OF ECONOMICS AND STATISTICS

APPENDIX A

Data Appendix

TABle A1.-BAses, RAtes, AND ECONOMic ENVIRONMENT

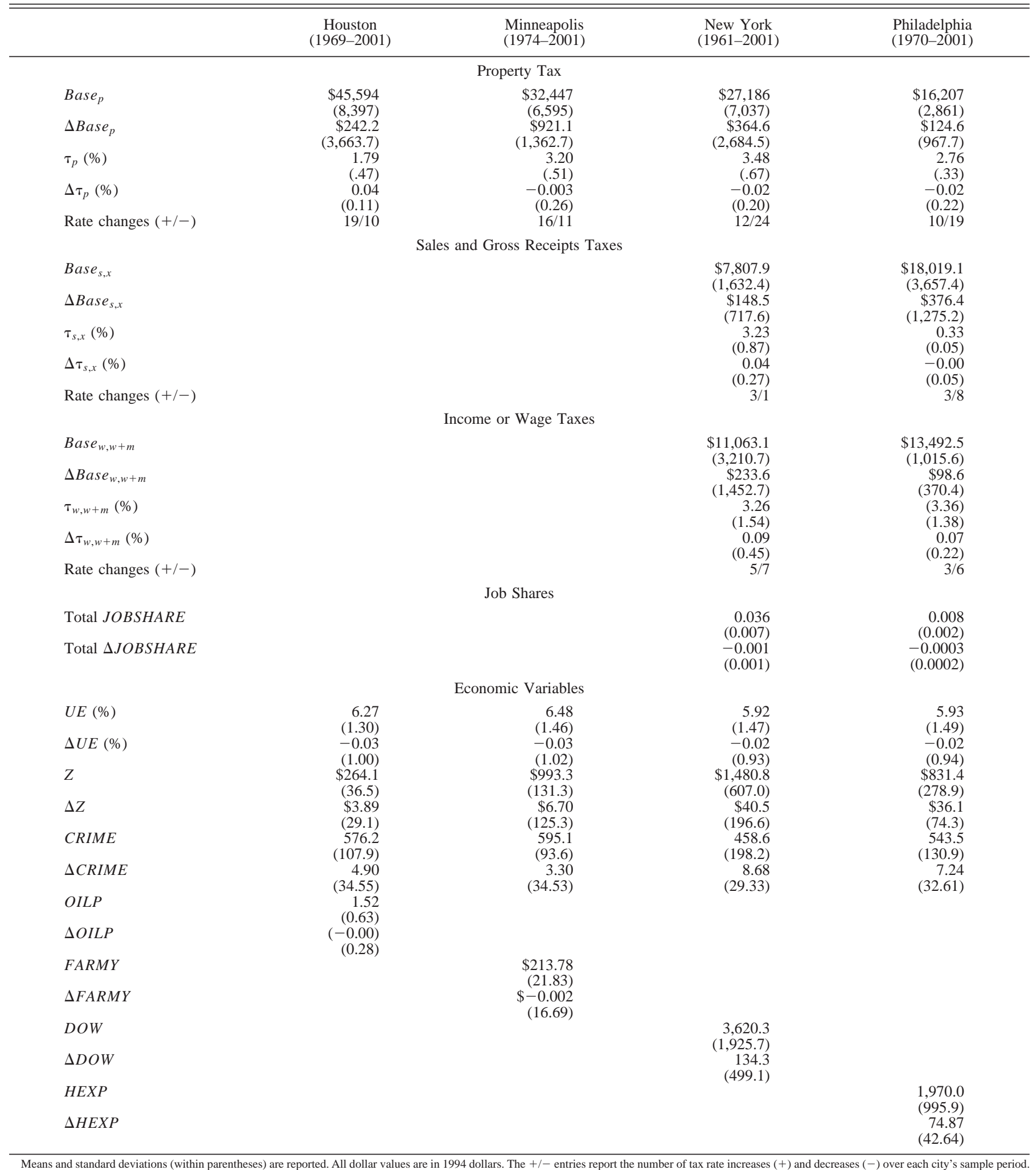

The variables UE, CRIME, OIL, FARMY, DOW, and HEXP are national values with means and standard deviations calculated for each city's sample period. 


\section{APPENDIX B}

\section{First-Stage Estimates for Changes in Local Tax Rates}

Table B1 summarizes the first-stage estimates used to predict changes in city tax rates for each of our sample cities. The dependent variable is the change in the local tax rate. Independent variables include a constant term, a time trend, the lagged national rate of unemployment, and then a set of excluded predetermined variables meant to be instruments for predicting changes in city rates. Possible instruments common to all cities include lagged unexpected state aid $\left(U A I D_{-1}\right)$, lagged changes in state income tax rates $\left(\Delta \tau_{S,-1}\right)$, lagged changes in the state's share of total state and local government spending $\left(\Delta S H R_{-1}\right)$, an indicator variable for the fiscal year prior to mayoral elections ( $E L E C T)$, and the local tax rate in the last year of the previous mayoral administration (PRATE). City-specific instruments include: changes in the state-allowed ratios of assessment rates for commercial and residential properties ( $\triangle A S S R A T I O$, Minneapolis), an indicator variable for FY 1987 to reflect the adoption of the federal tax reform in 1986 redefining the tax base for local income taxes linked to the federal income tax code (REFORM86, New York City), an indicator variable for FY 1977 to reflect the Philadelphia Federal Reserve Bank's revelation of the city's 1976 fiscal deficit (DEFICIT76, Philadelphia), an indicator variable for FY 1985 to reflect the 1984 state reform of city business taxation (BTX84, Philadelphia), and the change in the percentage share of minority representation on the Philadelphia City Council ( $\triangle M I N R E P$, Philadelphia), particularly dramatic following the conviction of six incumbent Council members for corruption in 1980. The final first-stage estimates use only those instrumental variables whose coefficients exceeded their standard errors; see table B1. Only coefficient estimates for the instruments are reported in table $\mathrm{B} 1$. Also reported in table $\mathrm{B} 1$ are the $R^{2}$ for each first-stage regression, the $F$-test statistic and associated $p$-values for the test of overall significance of the instruments in the first-stage regressions, and finally, the $\chi^{2}$ test statistic and associated $p$-values for the null hypothesis that the instruments are rightly excluded from the second-stage structural equation. In all cases, the instruments as a set are statistically significant determinants of changes in city tax rates (or, in the case of the New York City income tax rate, nearly so), and we cannot reject the null hypothesis that the instruments are appropriately excluded from the second-stage tax base equation.

Table B1.-First-Stage Estimates for Local Tax Rate Changes

\begin{tabular}{|c|c|c|c|c|c|c|c|c|}
\hline & \multirow{2}{*}{$\frac{\text { Houston }}{\Delta \tau_{p}}$} & \multirow{2}{*}{$\frac{\text { Minneapolis }}{\Delta \tau_{p}}$} & \multicolumn{3}{|c|}{ New York } & \multicolumn{3}{|c|}{ Philadelphia } \\
\hline & & & $\Delta \tau_{p}$ & $\Delta \tau_{s}$ & $\Delta \tau_{w}$ & $\Delta \tau_{p}$ & $\Delta \tau_{x}$ & $\Delta \tau_{w+m}$ \\
\hline$U A I D_{-1}$ & $\begin{array}{c}0.002 \\
(0.001)\end{array}$ & $\begin{array}{r}-0.0009 \\
(0.0007)\end{array}$ & $\begin{array}{r}-0.0005 \\
(0.0003)\end{array}$ & $\begin{array}{c}0.0008 \\
(0.0003)\end{array}$ & & $\begin{array}{c}0.003 \\
(0.001)\end{array}$ & & \\
\hline$\Delta \tau_{S,-1}$ & & & $\begin{array}{c}-0.136 \\
(0.137)\end{array}$ & & $\begin{array}{c}0.342 \\
(0.245)\end{array}$ & $\begin{array}{c}-0.173 \\
(0.117)\end{array}$ & & $\begin{array}{c}0.176 \\
(0.081)\end{array}$ \\
\hline$\Delta S H R_{-1}$ & $\begin{array}{c}2.45 \\
(1.33)\end{array}$ & & $\begin{array}{l}10.2 \\
(3.9)\end{array}$ & & & & & \\
\hline ELECT & & & $\begin{array}{r}-0.237 \\
(0.076)\end{array}$ & $\begin{array}{c}0.115 \\
(0.081)\end{array}$ & & & & \\
\hline PRATE & $\begin{array}{r}-0.178 \\
(0.107)\end{array}$ & $\begin{array}{r}-0.188 \\
(0.101)\end{array}$ & $\begin{array}{r}-0.187 \\
(0.061)\end{array}$ & & & $\begin{array}{c}0.050 \\
(0.033)\end{array}$ & $\begin{array}{c}0.295 \\
(0.263)\end{array}$ & \\
\hline$\triangle A S S R A T I O$ & & $\begin{array}{r}-0.299 \\
(0.119)\end{array}$ & & & & & & \\
\hline REFORM 86 & & & & & $\begin{array}{r}-0.894 \\
(0.481)\end{array}$ & & & \\
\hline DEFICIT76 & & & & & & $\begin{array}{c}0.907 \\
(0.147)\end{array}$ & $\begin{array}{c}0.100 \\
(0.049)\end{array}$ & $\begin{array}{c}0.883 \\
(0.189)\end{array}$ \\
\hline BTX84 & & & & & & $\begin{array}{r}-0.080 \\
(0.108)\end{array}$ & $\begin{array}{r}-0.055 \\
(0.036)\end{array}$ & $\begin{array}{c}0.199 \\
(0.138)\end{array}$ \\
\hline$\triangle M I N R E P$ & & & & & & $\begin{array}{c}-3.03 \\
(1.02)\end{array}$ & & \\
\hline$R^{2}$ & 0.418 & 0.455 & 0.528 & 0.227 & 0.392 & 0.734 & 0.285 & 0.610 \\
\hline$F$ & 3.08 & 4.31 & 3.60 & 3.46 & 2.35 & 9.10 & 2.78 & 7.02 \\
\hline ( $p$-value) & $(0.04)$ & $(0.01)$ & $(0.01)$ & $(0.04)$ & $(0.11)$ & $(0.001)$ & $(0.06)$ & $(0.001)$ \\
\hline $\begin{array}{l}\chi^{2} \\
(p \text {-value })\end{array}$ & $\begin{array}{c}2.06 \\
(0.36)\end{array}$ & $\begin{array}{c}1.53 \\
(0.46)\end{array}$ & $\begin{array}{c}1.32 \\
(0.86)\end{array}$ & $\begin{array}{c}1.12 \\
(0.29)\end{array}$ & $\begin{array}{c}0.39 \\
(0.53)\end{array}$ & $\begin{array}{c}3.39 \\
(0.64)\end{array}$ & $\begin{array}{c}0.06 \\
(0.97)\end{array}$ & $\begin{array}{c}5.86 \\
(0.12)\end{array}$ \\
\hline
\end{tabular}




\section{This article has been cited by:}

1. Howard Chernick, Santino Piazza. 2016. Fiscal gaps in amalgamated metropolitan areas: The case of Turin and Genoa. ECONOMIA PUBBLICA :1, 137-171. [CrossRef]

2. STEVEN G. CRAIG, EDWARD C. HOANG, DIETRICH VOLLRATH. 2015. Household Response to Government Debt: Evidence from Life Insurance Holdings. Journal of Money, Credit and Banking 47:5, 819-845. [CrossRef]

3. Sung Hoon Kang, Mark Skidmore, Laura Reese. 2015. The Effects of Changes in Property Tax Rates and School Spending on Residential and Business Property Value Growth. Real Estate Economics 43:2, 300-333. [CrossRef]

4. Robert Novy-Marx, Joshua Rauh. 2014. The Revenue Demands of Public Employee Pension Promises. American Economic Journal: Economic Policy 6:1, 193-229. [CrossRef]

5. Edward Glaeser. 2013. A Review of Enrico Moretti's The New Geography of Jobs. Journal of Economic Literature 51:3, 825-837. [CrossRef]

6. Edward L. GlaeserUrban Public Finance 195-256. [CrossRef]

7. Mark Skidmore, Laura Reese, Sung Hoon Kang. 2012. Regional analysis of property taxation, education finance reform, and property value growth. Regional Science and Urban Economics 42:1-2, 351-363. [CrossRef]

8. Jordi Jofre-Monseny, Albert Solé-Ollé. 2012. Which communities should be afraid of mobility? The effects of agglomeration economies on the sensitivity of employment location to local taxes. Regional Science and Urban Economics 42:1-2, 257-268. [CrossRef]

9. Bev Dahlby. 2011. The marginal cost of public funds and the flypaper effect. International Tax and Public Finance 18:3, 304-321. [CrossRef]

10. John P. Crank, Colleen Kadleck, Connie M. Koski. 2010. The USA: the next big thing. Police Practice and Research 11:5, 405-422. [CrossRef]

11. Jordi Jofre-Monseny, Albert Solé-Ollé. 2010. Tax Differentials in Intraregional Firm Location: Evidence from New Manufacturing Establishments in Spanish Municipalities. Regional Studies 44:6, 663-677. [CrossRef]

12. Edward L. Glaeser, Matt Resseger, Kristina Tobio. 2009. INEQUALITY IN CITIES. Journal of Regional Science 49:4, 617-646. [CrossRef]

13. Ralph M. Braid. 2009. The employment effects of a central city's source-based wage tax or hybrid wage tax. Regional Science and Urban Economics 39:4, 512-521. [CrossRef]

14. Jeffrey I. Chapman. 2008. State and Local Fiscal Sustainability: The Challenges. Public Administration Review 68, S115-S131. [CrossRef]

15. SUSANA PERALTA. 2007. Political Support for Tax Decentralization. Journal of Public Economic Theory 9:6, 1013-1030. [CrossRef] 